\title{
Microplastics in sediments: A review of techniques, occurrence and effects
}

\author{
Van Cauwenberghe Lisbeth ${ }^{1,}{ }^{\text {, }}$, Devriese Lisa ${ }^{2}$, Galgani Francois ${ }^{3}$, Robbens Johan ${ }^{2}$, \\ Janssen Colin R.
}

${ }^{1}$ Ghent University, Laboratory of Environmental Toxicology and Aquatic Ecology, Jozef Plateaustraat 22, 9000 Ghent, Belgium

${ }^{2}$ Institute of Agricultural and Fisheries Research, Animal Sciences Unit - Aquatic Environment and Quality, Ankerstraat 1, 8400 Ostend, Belgium

${ }^{3}$ IFREMER, LER/PAC, Bastia, France

* Corresponding author : Lisbeth Van Cauwenberghe, Tel.: +32 926437 07; fax: +32 92643766 ;

email address : lisbeth.vancauwenberghe@ugent.be

\begin{abstract}
:
Microplastics are omnipresent in the marine environment and sediments are hypothesized to be major sinks of these plastics. Here, over 100 articles spanning the last 50 year are reviewed with following objectives: (i) to evaluate current microplastic extraction techniques, (ii) to discuss the occurrence and worldwide distribution of microplastics in sediments, and (iii) to make a comprehensive assessment of the possible adverse effects of this type of pollution to marine organisms. Based on this review we propose future research needs and conclude that there is a clear need for a standardized techniques, unified reporting units and more realistic effect assessments.
\end{abstract}

\section{Highlights}

An in-depth analysis of literature regarding microplastics in sediments was performed. Extraction techniques, occurrence and distribution, and impacts were discussed. There is a clear need for standardisation and harmonisation of techniques. Effect assessments should represent more realistic exposure conditions.

Keywords : Microplastics, Pellets, Sediment, Techniques, Direct effects, Indirect effects 


\section{INTRODUCTION}

Plastic has changed the way we live. It possesses a unique set of properties making it extremely popular for use in everyday life: it can be used at a wide range of temperatures, has low thermal conductivity, a high strength-to-weight ratio, is bio-inert, durable and above all it is cheap (Andrady, 2011; Andrady and Neal, 2009). This has led to the use of plastic in a myriad of applications, ranging from household and personal goods, clothing and packaging to construction materials. As a result, the global plastic production has grown exponentially ever since its mass production started in the 1950s, with 288 million tonnes produced worldwide in 2012 (PlasticsEurope, 2013). Even though the societal benefits of plastic are undeniable (Andrady and Neal, 2009), there are some serious environmental concerns associated with the material. While a part of the plastic waste is properly managed (through combustion or recycling), is has been estimated that millions of tonnes of plastic waste (4.8 to 12.7 million tonnes in 2010) end up the marine environment (Jambeck et al., 2015).

Plastics are present in the environment in a wide variety of sizes, ranging from metres to micrometers (Barnes et al., 2009). The smallest form of plastic litter is called microplastic. These are present in the environment as 'microplastics by design', so-called primary microplastics, or arise from the degradation of larger plastic litter. While the former are typically resin pellets and microbeads associated with industrial spillages (EPA, 1992) and the use of cosmetics (Fendall and Sewell, 2009; Zitko and Hanlon, 1991), the latter (secondary microplastics) are formed through the action of degrading forces such as UV radiation and physical abrasion (Barnes et al., 2009; Cole et al., 2011). Another important source comes from synthetic clothing: a single synthetic garment can release up to 1900 fibres per washing cycle (Browne et al., 2011).

At present, there is no universally accepted definition regarding the size of microplastics. When first described in 2004, the term microplastic was adopted to refer to microscopic plastic debris in the $20 \mu \mathrm{m}$ region (Thompson et al., 2004). A motion to broaden the definition to all fragments smaller than $5 \mathrm{~mm}$ was made in 2009 (Arthur et al., 2009). While the value of $5 \mathrm{~mm}$ is more commonly accepted, the $1 \mathrm{~mm}$ upper size limit is a more intuitive one as 'micro' refers to the micrometer range. As a result, this more strict definition is also often used in scientific literature (e.g. Browne et al., 2011; Claessens et al., 2011; Van Cauwenberghe et al., 2013; Vianello et al., 2013; Dekiff et al., 2014).

Microplastics have been reported in the water column and marine sediments worldwide (Claessens et al., 2011; Law et al., 2010; Moore et al., 2001; Thompson et al., 2004). While the first reports on microplastics in surface waters already date back to the early 1970s (Carpenter et al., 
1972; Carpenter and Smith, 1972), it took another 5 years until the first records of plastic pellets on beaches were made (Gregory, 1977, 1983; Shiber, 1979) and another thirty years until the first microplastics ( $<1 \mathrm{~mm}$ ) in sediments were reported (Thompson et al., 2004). Sediments are suggested to be a long-term sink for microplastics (Cózar et al., 2014; Law et al., 2010; Morét-Ferguson et al., 2010). Logically, plastics with a density that exceeds that of seawater $\left(>1.02 \mathrm{~g} . \mathrm{cm}^{-3}\right)$ will sink and accumulate in the sediment, while low-density particles tend to float on the sea surface or in the water column. However, through density-modification even low-density plastics can reach the seafloor. Biomass accumulation due to biofouling can lead to an increase in density resulting in the sinking of the microplastic (Andrady, 2011; Reisser et al., 2013; Zettler et al., 2013). Using nitrogen as a proxy, Morét-Ferguson et al. (2010) concluded that the reported change in microplastic density is due to attached biomass. Indeed, analysis of polyethylene bags submerged in seawater for 3 weeks showed a significant increase in biofilm formation over time, accompanied by corresponding changes in physicochemical properties of the plastic, such as a decrease in buoyancy (Lobelle and Cunliffe, 2011). These studies suggest that biofouling can contribute towards the settling and eventual burial in sediments of previously buoyant plastic. Biomass accumulation on plastic may even partly explain the recent finding that the global plastic load in the open-ocean surface is estimated to be two orders of magnitude lower than expected from estimates of plastic releases in the marine environment (Cózar et al., 2014).

The main objective of this review is to assess the state of the science in the exposure and effects assessment of microplastics in the marine environment, more specifically in marine sediments. This was achieved by analysing available literature to: (1) provide an in-depth evaluation of the current and commonly used techniques for extracting microplastics from sediments, (2) discuss the occurrence and distribution of microplastics in marine sediments worldwide and (3) make a comprehensive assessment of the known effects to benthic and sediment-associated wildlife.

\section{REVIEW OF AVAILABLE LITERATURE}

We conducted an extensive literature review using the ISI Web of Knowledge and Google Scholar databases. Based on the search parameters detailed below, a total of 122 original publications were retrieved, dating back to 1977. The majority of publications (90\%) were published from 2004 onwards, with $75 \%$ of all literature published in the last five years (Figure 1). Next to peer-reviewed papers, conference proceedings, posters and dissertations were also included in this review. 
From these publications, all necessary information regarding (i) the extraction technique, (ii) microplastic abundance and distribution and in the case of effect assessments (iii) exposure concentration and observed effects was extracted and processed.

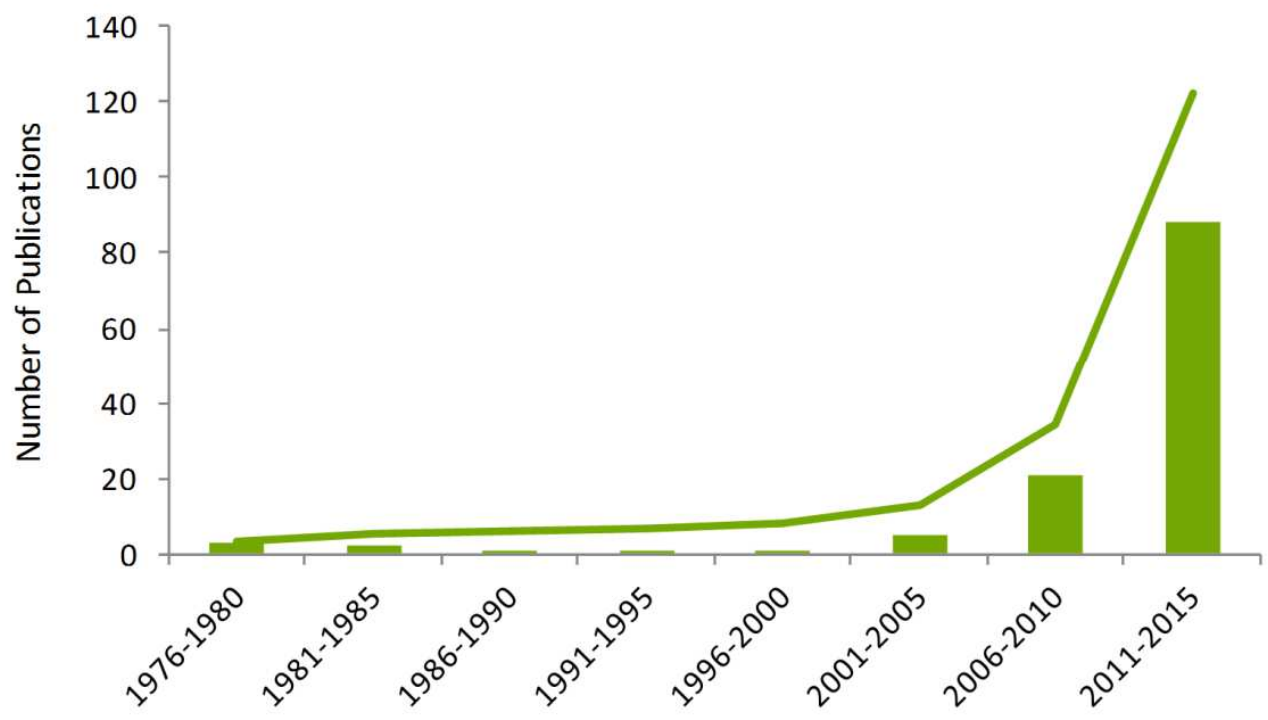

Figure 1: Evolution in the publication of 'microplastic in sediment' literature. The bars represent the number of publications published in the corresponding 5 -year period, while the curve represents the cumulative distribution of the published literature since 1975.

In the ISI Web of Knowledge, a literature search using the keywords 'plastic pellet or microplastic' in combination with 'sediment or beach' generated a list of 139 peer-reviewed papers. These date back to 1982 and cover the period until the beginning of 2015. From these publications a list of 32 papers on occurrence and distribution, 9 reviews and 5 papers presenting and discussing extraction techniques was compiled. An additional search on the Google Scholar search engine, using the same keywords, yielded and additional 19 publications, posters and dissertations on occurrence and distribution of microplastics in sediments (1977-2015).

Using the ISI Web of Knowledge database, the queries 'microplastic, organism, ingestion' and 'microplastic contaminant or microorganism' resulted in two publication lists of 18 original publications each. These publications go back to 1994 and cover the period until the beginning of 2015. Still, this collection of publications revealed not all the relevant information on the direct and indirect effects of microplastics to epibenthic species. The Google Scholar search engine revealed additional hits for these queries, including conference posters, conference proceedings and dissertations. From these lists, a final relevant literature list of 57 publications, posters and dissertations was composed. 
Due to the rapid development of microplastic research, there is a lack of consistency in sampling and extraction techniques used to quantify microplastics in sediments. As a result of the large variety in techniques applied, comparison of reported microplastic concentrations between studies is often impossible or requires additional calculations based on assumptions (e.g. sediment densities). The majority of these method inconsistencies can be related to (i) differences in the lower and upper size limit implemented, (ii) the sensitivity of the applied extraction technique and (iii) differences in sampling technique leading to a wide variety of reporting units.

The lack of an unequivocal size-based definition of microplastic has resulted in the reporting of several different size fractions in literature, all using the same term: microplastics. In practice, this means that the results of a substantial body of microplastic literature cannot be compared directly. As microplastics include particles up to $5 \mathrm{~mm}$ (Arthur et al., 2009) and both extraction and identification becomes more challenging with decreasing dimensions, authors often opt to only include plastics larger than $1 \mathrm{~mm}$ (e.g. Baztan et al., 2014; Jayasiri et al., 2013; McDermid and McMullen, 2004) or even >2 mm (e.g. Heo et al., 2013; Ivar do Sul et al., 2009; Turner and Holmes, 2011). Even among those studies that do include the smallest of microplastics (down to $1.6 \mu \mathrm{m}$ ) different upper size limits are applied: either $1 \mathrm{~mm}$ (Browne et al., 2011; Browne et al., 2010; Claessens et al., 2011; Van Cauwenberghe et al., 2013a) or 5 mm (Martins and Sobral, 2011; Mathalon and Hill, 2014; Ng and Obbard, 2006; Reddy et al., 2006). As both different lower and upper size limits are used throughout microplastic literature, a vast amount of data on microplastic occurrence and distribution worldwide is lost. Yet, this inconsistent use of the term 'microplastic' can be easily addressed by introducing a more comprehensive classification to differentiate between small microplastics (SMPs: $<1 \mathrm{~mm}$ ) and large microplastics (LMPs: 1-5 mm) (Figure 2) as proposed by European MSFD technical subgroup on Marine Litter (Galgani et al., 2013). Another earlier study suggests the following: micro- $(<0.5 \mathrm{~mm})$ and mesolitter $(0.5-10 \mathrm{~mm})$ (Gregory and Andrady, 2003). While the discussion often focuses on the upper size limit of microplastics, it can be argued that the adoption of a lower size limit is equally important. To date, the lower size limit used in microplastic assessment studies is highly dependent on the sensitivity of the sampling and extractions techniques applied. Often, the technical constraints associated with the extraction of small microplastics (SMPs) result in the omission of this lower size limit. However, not including the sub-1 $\mathrm{mm}$ fraction can result in reporting highly underestimated concentrations. Indeed, it has been demonstrated repeatedly that these small microplastics represent $35-90 \%$ of all microplastics present in the marine environment (Browne et al., 2010; Eriksen et al., 2013; McDermid and McMullen, 2004; Song et al., 2014; Zhao et al., 2014). 


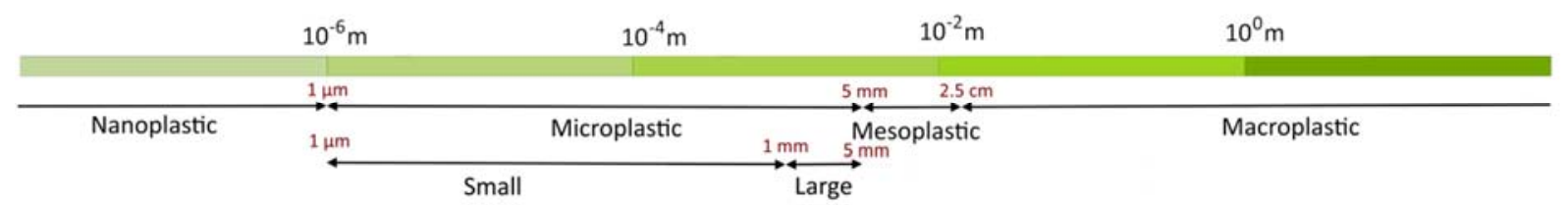

Figure 2: Size matters. Suggestion of plastic debris nomenclature based on size, as proposed by the European MSFD technical subgroup on Marine Litter (MSFD GES Technical Subgroup on Marine Litter, 2013). The overall term "microplastic" is composed of small microplastics (SMPs, smaller than $1 \mathrm{~mm}$ ) and large microplastics (LMPs, 1 to $5 \mathrm{~mm}$ ), to differentiate between two commonly used definitions of microplastics.

A wide range of sampling techniques is used for monitoring microplastics in sediments (reviewed in Hidalgo-Ruz et al., 2012 and Rocha-Santos \& Duarte, 2015). As a result, the reported abundances are often expressed in different units. While a simple conversion can sometimes be made to compare among studies, often comparison is impossible or requires assumptions that lead to biased results. The choice of sampling strategy and sampling approach (reviewed by Hidalgo-Ruz et al., 2012) will eventually determine the unit in which observed abundances will be reported. Those studies sampling an area (using quadrants) will often report abundances per unit of surface ( $\mathrm{m}^{2}$; e.g. Ivar do Sul et al., 2009; Lee et al., 2013; Martins and Sobral, 2011). If areal bulk samples up to a specific depth are taken the reporting unit is $\mathrm{m}^{3}$ (e.g. Ballent et al., 2012; Turra et al., 2014). Conversion between these type of abundances is possible, if sufficient information is available on sampling depth. Yet, for $20 \%$ of the studies this is not the case as reported sampling depths can range from 0 to $50 \mathrm{~cm}$. Other widely used reporting units are volume $(\mathrm{mL}$ to L; e.g. McDermid and McMullen, 2004; Norén, 2007; Thompson et al., 2004) or weight (g to kg; e.g. Claessens et al., 2011; $\mathrm{Ng}$ and Obbard, 2006; Reddy et al., 2006). Conversion between these two types of units is not straight forward as detailed information on the density of the sediment is required. As this is never (as far as we could establish) reported in microplastic studies, assumptions have to be made, as Claessens et al. (2011) did for the conversion of microplastic abundances in sediment. Additionally, within studies reporting weight, a distinction can be made among those reporting wet (sediment) weight and those reporting dry weight. This adds to the constraints of converting from weight to volume units, or vice versa. Sediment samples from different locations or even different zones on one beach (e.g. high littoral vs. sub littoral zone) have different water content. Therefore, a (limited) number of authors choose to express microplastic concentrations as dry weight eliminate this variable (Claessens et al., 2011; Dekiff et al., 2014; Ng and Obbard, 2006; Nor and Obbard, 2014; Van Cauwenberghe et al., 2013a; Vianello et al., 2013).

After sampling, either from beach sediments or the seabed, different approaches can be used to separate the microplastic fragments from the sandy or muddy matrix. The most common approach is to extract plastic particles from the sediment using a density separation, based on the differences in 
density between plastic and sediment particles. Typically, this is achieved by agitating the sediment sample in concentrated sodium chloride ( $\mathrm{NaCl}$ ) solution, as described by Thompson et al. (2004). However, as the density of the $\mathrm{NaCl}$ solution is only $1.2 \mathrm{~g} . \mathrm{cm}^{-3}$, only low-density plastics will float to the surface and can hence be extracted. Different authors have addressed this issue by using different salt solutions to obtain higher densities. Liebezeit et al. (2012) and Imhof et al. (2013) extracted microplastics from sediments using zinc chloride $\left(\mathrm{ZnCl}_{2}, 1.5-1.7 \mathrm{~g} . \mathrm{cm}^{-3}\right)$, while others (Dekiff et al., 2014; Van Cauwenberghe et al., 2013a; Van Cauwenberghe et al., 2013b) used a sodium iodide (Nal, $1.6-1.8 \mathrm{~g} . \mathrm{cm}^{-3}$ ) solution. These modifications of the commonly used method of Thompson et al. (2004) result in an increased extraction efficiency for high-density microplastics such

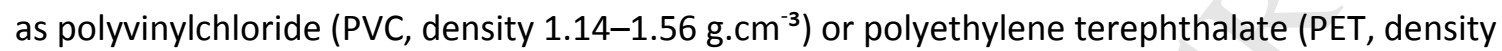
$1.32-1.41{\mathrm{~g} . \mathrm{cm}^{-3}}^{-3}$. As these high-density plastics make up over $17 \%$ of the global plastic demand (PlasticsEurope, 2013), not including these types of microplastic can result in a considerable underestimation of microplastic abundances in sediments. Especially as these high-density plastics are the first to settle and incorporate into marine sediments (density of seawater is $1.02 \mathrm{~g} . \mathrm{cm}^{-3}$ ).

As sampling, extraction and detection methods and techniques are being developed worldwide (Claessens et al., 2013; Fries et al., 2013; Harrison et al., 2012; Imhof et al., 2012; Nuelle et al., 2014) it is clear that in order to completely understand the distribution of microplastics in the marine environment, a harmonisation and standardisation of techniques and protocols is urgently needed to enhance microplastic research and monitoring.

\section{OCCURRENCE OF MICROPLASTICS IN SEDIMENTS}

The first reports of microplastics associated with sediments date back to the late 1970s. These early observations comprised industrial resin pellets $(2-5 \mathrm{~mm})$ on beaches in New Zealand, Canada, Bermuda, Lebanon and Spain (Gregory, 1977, 1978, 1983; Shiber, 1979, 1982), demonstrating already back then- their worldwide distribution. Even in these first reports, pellet concentrations regularly exceeded 1000 pellets per metre of beach, with extreme abundances reported from 20000 to 100000 pellets. $\mathrm{m}^{-1}$ (Gregory, 1978). Large ports and local plastic industry were considered major sources, while for Bermuda -which lacks such local sources- the influence of oceanic circulation patterns (located in the west of the North Atlantic Gyre) explain the high concentrations. (Gregory, 1983). Large numbers of beached industrial pellets in association with labelled, intact bags detected on beaches in the United Arabian Emirates and Oman confirmed the importance of local contamination sources (Khordagui and Abu- Hilal, 1994). Ever since these first studies, pellet contamination of beaches worldwide has been reported (Table 1). For the majority of these studies the main focus was not to assess the occurrence and abundance of these pellets, but rather to 
evaluate the contaminant load present on these pellets. Indeed, their size, long environmental persistence and worldwide distribution, make them especially suitable for chemical analysis (Mato et al., 2001). Many hydrophobic compounds (including polychlorinated biphenyls (PCBs), polycyclic aromatic hydrocarbons (PAHs), dichlorodiphenyltrichloroethane (DDT) and degradation products) have been detected on pellets collected from marine environments. Concentrations of PCBs on polypropylene pellets collected in Japan were up to $10^{6}$ times that of the surrounding seawater

234 (Mato et al., 2001). Recently, Fotopoulou and Karapanagioti (2012) demonstrated that surface

235 alterations in pellets, resulting from environmental erosion, can explain the increased affinity for contaminants of pellets (Endo et al., 2005). While virgin pellets have smooth and uniform surfaces, eroded pellets exhibited an uneven surface with an increased surface area and polarity, affecting the

238 efficiency of sorption (Fotopoulou and Karapanagioti, 2012).

Table 1: Available literature on pollution of marine sediments by industrial resin pellets. Origin and main focus of the research (i.e. assessing occurrence and abundance, assessing contaminant load or investigating surface characteristics) is provided.

\begin{tabular}{|c|c|c|c|}
\hline Continent & Location & Main focus & Reference \\
\hline \multirow{3}{*}{ Africa } & Canary Islands & Contaminant load & Heskett et al., 2011 \\
\hline & Saint Helena & Contaminant load & Heskett et al., 2011 \\
\hline & South Africa & Contaminant load & Ryan et al., 2012 \\
\hline \multirow{12}{*}{ America } & Barbados & Contaminant load & Heskett et al., 2011 \\
\hline & Bermuda & Occurrence & Gregory, 1983 \\
\hline & \multirow{4}{*}{ Brazil } & Occurrence & Costa et al., 2010 \\
\hline & & Occurrence & Turra et al., 2014 \\
\hline & & Contaminant load & Fisner et al., 2013a \\
\hline & & Contaminant load & Fisner et al., 2013b \\
\hline & \multirow{2}{*}{ California } & Contaminant load & Rios et al., 2007 \\
\hline & & Contaminant load & Van et al., 2012 \\
\hline & Canada & Occurrence & Gregory, 1983 \\
\hline & \multirow{3}{*}{ Hawaii } & Occurrence & McDermid and McMullen, 2004 \\
\hline & & Contaminant load & Rios et al., 2007 \\
\hline & & Contaminant load & Heskett et al., 2011 \\
\hline \multirow{10}{*}{ Asia } & Cocos Islands & Contaminant load & Heskett et al., 2011 \\
\hline & Hong Kong & Contaminant load & Zurcher, 2009 \\
\hline & & Contaminant load & Mato et al., 2001 \\
\hline & Japan & Contaminant load & Endo et al., 2005 \\
\hline & $>$ & Characteristics & Kuriyama et al., 2002 \\
\hline & Jordan & Occurrence & Abu-Hilal and Al-Najjar, 2009 \\
\hline & Lebanon & Occurrence & Shiber, 1979 \\
\hline & Malaysia & Occurrence & Ismail et al., 2009 \\
\hline & Oman & Occurrence & Khordagui and Abu-Hilal, 1994 \\
\hline & United Arabian Emirates & Occurrence & Khordagui and Abu-Hilal, 1994 \\
\hline \multirow{2}{*}{ Australia } & \multirow{2}{*}{ New Zealand } & Occurrence & Gregory, 1977 \\
\hline & & Occurrence + Contaminant load & Gregory, 1978 \\
\hline \multirow{7}{*}{ Europe } & Belgium & Occurrence & Van Cauwenberghe et al., 2013a \\
\hline & \multirow{2}{*}{ Greece } & Contaminant load & Karapanagioti and Klontza, 2008 \\
\hline & & Contaminant load & Karapanagioti et al., 2011 \\
\hline & Malta & Occurrence + Characteristics & Turner and Holmes, 2011 \\
\hline & \multirow{3}{*}{ Portugal } & Contaminant load & Frias et al., 2010 \\
\hline & & Occurrence + Contaminant load & Antunes et al., 2013 \\
\hline & & Contaminant load & Mizukawa et al., 2013 \\
\hline
\end{tabular}




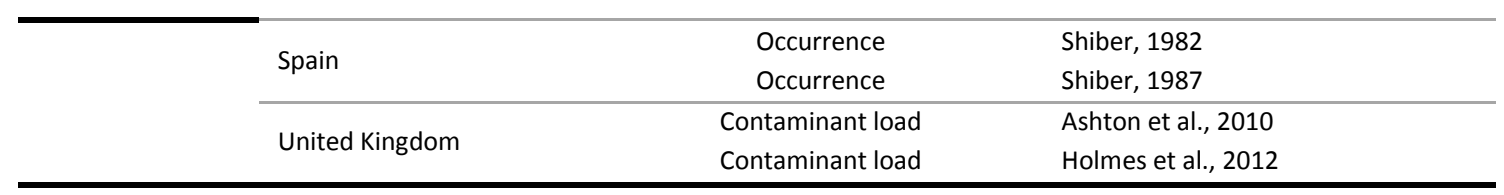

While the occurrence of industrial resin pellets in marine environments were already described

244 in the 1970s, it took another 30 years before the first reports on other types of microplastics were

245 published. By analysing subtidal, estuarine and sandy sediments from 18 locations across the UK,

246 Thompson et al. (2004) were the first to demonstrate the presence of $\mu \mathrm{m}$-sized $(<1 \mathrm{~mm})$

247 microplastics in marine sediments. Soon, reports from Singapore (Ng and Obbard, 2006), India

248 (Reddy et al., 2006) and Sweden (Norén, 2007) illustrated the widespread distribution of these small

249 microplastics. Currently, small and large microplastics are detected in sediments worldwide:

250 especially beaches, subtidal and offshore sediments have been examined (Table 2, Figure 3).

251 Recently, even deep oceanic sediments have been shown to contain microplastics: up to 2000

252 particles per $\mathrm{m}^{2}$ are detected in sediments at a depth of $5000 \mathrm{~m}$ (Fisher et al., 2015; Van

253 Cauwenberghe et al., 2013b). It has also been demonstrated that the level of plastic pollution is

254 increasing: sediment core analysis revealed that over the last 20 years microplastic deposition on

255 Belgian beaches tripled (Claessens et al., 2011).

Table 2: Abundance of microplastics in sediments worldwide. Location and location specification (i.e. 'sediment type') are provided, as well as the microplastic size range (particle size) applied during the assessment.

\begin{tabular}{|c|c|c|c|c|c|}
\hline Continent & Location & $\begin{array}{l}\text { Location } \\
\text { specification }\end{array}$ & Particle size & Measured abundance & Reference \\
\hline Africa & Canary Islands & Beach & $1 \mathrm{~mm}-5 \mathrm{~mm}$ & $<1->100 \mathrm{~g} / \mathrm{L}$ & Baztan et al., 2014 \\
\hline \multirow{9}{*}{ America } & Hawaii & Beach & $1 \mathrm{~mm}-15 \mathrm{~mm}$ & $541-18,559$ items/260 L & McDermid \& McMullen, 2004 \\
\hline & US & $\begin{array}{l}\text { Florida subtidal } \\
\text { Maine subtidal }\end{array}$ & $250 \mu \mathrm{m}-4 \mathrm{~mm}$ & $\begin{array}{c}116-215 \text { items/L } \\
105 \text { items/L }\end{array}$ & Graham \& Thompson, 2009 \\
\hline & Brazil & Beach & $2 \mathrm{~mm}-5 \mathrm{~mm}$ & 60 items $/ \mathrm{m}^{2}$ & Ivar do Sul et al., 2009 \\
\hline & Brazil & & $\begin{array}{l}0.5 \mathrm{~mm}-1 \mathrm{~mm} \\
1 \mathrm{~mm}-20 \mathrm{~mm}\end{array}$ & $\begin{array}{l}200 \text { items/0.01 m² } \\
100 \text { items } / 0.01 \mathrm{~m}^{2}\end{array}$ & Costa et al., 2010 \\
\hline & Hawaii & Beach & $250 \mu \mathrm{m}-10 \mathrm{~mm}$ & $0.12 \%-3.3 \%$ plastic by weight & Carson et al., 2011 \\
\hline & Brazil & Tidal plain & $1 \mathrm{~mm}-10 \mathrm{~cm}$ & $6.36-15.89$ items $/ \mathrm{m}^{2}$ & Costa et al., 2011 \\
\hline & Chile & Beach & $1 \mathrm{~mm}-4.75 \mathrm{~mm}$ & $<1-805$ items $/ \mathrm{m}^{2}$ & Hidalgo-Ruz \& Thiel, 2013 \\
\hline & Québec & River sediment & $400 \mu \mathrm{m}-2.16 \mathrm{~mm}$ & $52-13,832$ beads $/ \mathrm{m}^{2}$ & Castañeda et al., 2014 \\
\hline & Nova Scotia & Beach & $0.8 \mu \mathrm{m}-5 \mathrm{~mm}$ & $20-80$ fibres/10 g & Mathalon \& Hill, 2014 \\
\hline \multirow{8}{*}{ Asia } & Singapore & Beach & $1.6 \mu \mathrm{m}-5 \mathrm{~mm}$ & $0-4$ items $/ 250 \mathrm{~g}$ dry & $\mathrm{Ng} \&$ Obbard, 2006 \\
\hline & India & Ship-breaking yard & $1.6 \mu \mathrm{m}-5 \mathrm{~mm}$ & $81.4 \mathrm{mg} / \mathrm{kg}$ & Reddy et al., 2006 \\
\hline & South Korea & High tide line & $2 \mathrm{~mm}-10 \mathrm{~mm}$ & 913 items $/ \mathrm{m}^{2}$ & Heo et al., 2013 \\
\hline & India & Beach & $1 \mathrm{~mm}-5 \mathrm{~mm}$ & $10-180$ items $/ \mathrm{m}^{2}$ & Jayasiri et al., 2013 \\
\hline & South Korea & $\begin{array}{l}\text { Beach dry season } \\
\text { Beach rainy season }\end{array}$ & $1 \mathrm{~mm}-5 \mathrm{~mm}$ & $\begin{array}{c}8,205 \text { items } / \mathrm{m}^{2} \\
27,606 \text { items } / \mathrm{m}^{2}\end{array}$ & Lee et al., 2013 \\
\hline & Singapore & Mangrove & $1.6 \mu \mathrm{m}-5 \mathrm{~mm}$ & 36.8 items/kg dry & Nor \& Obbard, 2014 \\
\hline & NW Pacific & Deep sea trench & $300 \mu \mathrm{m}-5 \mathrm{~mm}$ & $60-2,020$ items $/ \mathrm{m}^{2}$ & Fisher et al., 2015 \\
\hline & South Korea & Beach & $50 \mu \mathrm{m}-5 \mathrm{~mm}$ & $56-285,673$ items $/ \mathrm{m}^{2}$ & Kim et al., 2015 \\
\hline Europe & UK & $\begin{array}{l}\text { Beach } \\
\text { Estuary }\end{array}$ & $1.6 \mu \mathrm{m}-5 \mathrm{~mm}$ & $\begin{array}{l}0.4 \text { fibres } / 50 \mathrm{~mL} \\
2.4 \text { fibres } / 50 \mathrm{~mL}\end{array}$ & Thompson et al., 2004 \\
\hline
\end{tabular}


ACCEPTED MANUSCRIPT

\begin{tabular}{|c|c|c|c|c|c|}
\hline & & Subtidal & & 5.6 fibres $/ 50 \mathrm{~mL}$ & \\
\hline & Sweden & Subtidal & $2 \mu m-5 m m$ & $2-332$ items/100 mL & Norén, 2007 \\
\hline & UK & Beach & $1.6 \mu \mathrm{m}-1 \mathrm{~mm}$ & $<1-8$ items $/ 50 \mathrm{~mL}$ & Browne et al., 2010 \\
\hline & UK & $\begin{array}{l}\text { North Sea beach } \\
\text { English Ch. beach }\end{array}$ & $38 \mu \mathrm{m}-1 \mathrm{~mm}$ & $\begin{array}{c}0.2-0.8 \text { fibres } / 50 \mathrm{~mL} \\
0.4-1 \text { fibres } / 50 \mathrm{~mL}\end{array}$ & Browne et al., 2011 \\
\hline & & Harbour & & 166.7 items/kg dry & \\
\hline & Belgium & Continental Shelf & $38 \mu \mathrm{m}-1 \mathrm{~mm}$ & 97.2 items/kg dry & Claessens et al., 2011 \\
\hline & & Beach & & 92.8 items/kg dry & \\
\hline & Portugal & Beach & $1.2 \mu \mathrm{m}-5 \mathrm{~mm}$ & 133.3 items $/ \mathrm{m}^{2}$ & Martins \& Sobral, 2011 \\
\hline & Germany & $\begin{array}{l}\text { Urban beach } \\
\text { Rural beach }\end{array}$ & $1 \mathrm{~mm}-15 \mathrm{~mm}$ & $\begin{array}{c}5000-7000 \text { items } / \mathrm{m}^{3} \\
150-700 \text { items } / \mathrm{m}^{3}\end{array}$ & Ballent et al., 2012 \\
\hline & Germany & Tidal flat & $1.2 \mu \mathrm{m}-5 \mathrm{~mm}$ & $0-621$ items $/ 10 \mathrm{~g}$ & Liebezeit \& Dubaish, 2012 \\
\hline & Italy & Sub-alpine lake & $9 \mu m-5 m m$ & 1108 items $/ \mathrm{m}^{2}$ & Imhof et al., 2013 \\
\hline & Greece & Beach & $\begin{array}{l}1 \mathrm{~mm}-2 \mathrm{~mm} \\
2 \mathrm{~mm}-4 \mathrm{~mm}\end{array}$ & $\begin{array}{l}57-602 \text { items } / \mathrm{m}^{2} \\
10-575 \text { items } / \mathrm{m}^{2}\end{array}$ & Kaberi et al., 2013 \\
\hline & Belgium & $\begin{array}{l}\text { High tide line } \\
\text { Low tide line }\end{array}$ & $38 \mu \mathrm{m}-1 \mathrm{~mm}$ & $\begin{array}{l}9.2 \text { items/kg dry } \\
17.7 \text { items/kg dry }\end{array}$ & $\begin{array}{l}\text { Van Cauwenberghe et al., } \\
2013\end{array}$ \\
\hline & Italy & Subtidal & $0.7 \mu \mathrm{m}-1 \mathrm{~mm}$ & $672-2175$ items/kg dry & Vianello et al., 2013 \\
\hline & Germany & Beach & $<1 \mathrm{~mm}$ & $1.3-2.3$ items $/ \mathrm{kg}$ dry & Dekiff et al., 2014 \\
\hline & Slovenia & $\begin{array}{l}\text { Beach } \\
\text { Infralittoral }\end{array}$ & $0.25-5 \mathrm{~mm}$ & $\begin{array}{l}177.8 \text { items/kg dry } \\
170.4 \text { items/kg dry }\end{array}$ & Laglbauer et al., 2014 \\
\hline Worldwide & & Deep sea & $5 \mu \mathrm{m}-1 \mathrm{~mm}$ & 0.5 items $/ \mathrm{cm}^{2}$ & $\begin{array}{l}\text { Van Cauwenberghe et al., } \\
2013\end{array}$ \\
\hline
\end{tabular}
shoreline), others studied specific littoral zones. As was already remarked by Hidalgo-Ruz et al. (2012), this lack in uniformity between studies explains why the distribution of microplastics on beaches is still little understood, and that there is a need to systematically examine potential accumulation zones of microplastics. In a recent attempt to elucidate the distribution of microplastics across the different beach zones, Heo et al. (2013) analysed the entire cross section (from back- to foreshore) of an impacted South Korean beach. Their results indicated that, unlike macroplastics,

268 which accumulated at the high tide line, microplastics $(2-10 \mathrm{~mm})$ were most abundant in the upper 269 intertidal zone, closer to the backshore. These results indicate that the mechanisms influencing 270 macroplastic distribution on beaches, like wind and currents (Carson et al., 2013a; Thornton and 271 Jackson, 1998), affect microplastic distribution in a different way. As a result, choosing the 272 appropriate site or zone for microplastic assessment on beaches may not be as straight forward as 273 previously thought, yet presents a critical factor in the assessment of microplastic pollution in coastal regions (Kim et al., 2015). 


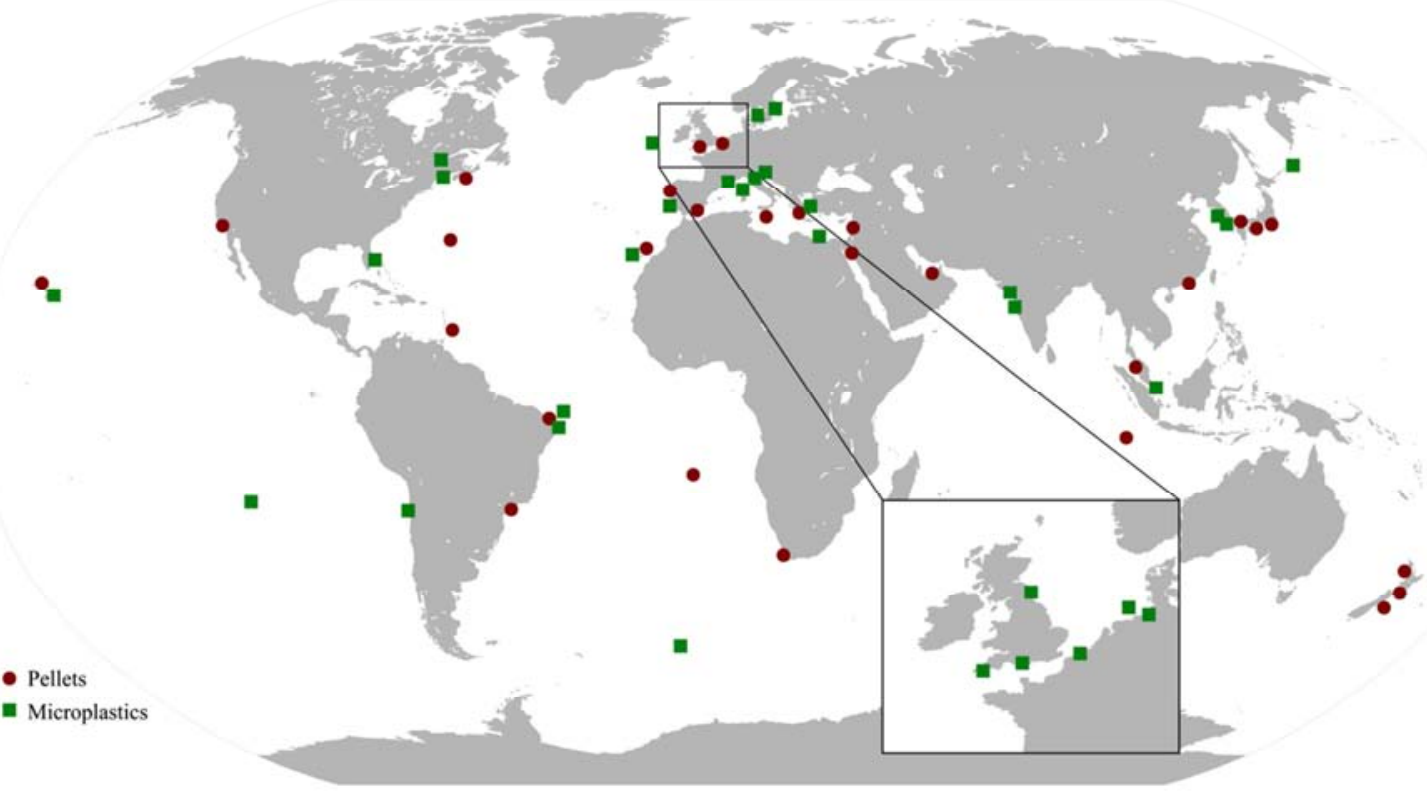

Figure 3. Geographical distribution of studies reporting industrial resin pellets and other microplastic types in sediments. Black circles indicate studies that reported on the abundance or presence of industrial resin pellets, black squares indicate studies that focus on other microplastic types (i.e. fragments, microbeads and fibres).

Differences in macro- versus microplastic distribution on beaches was also demonstrated by Browne et al. (2010) in the Tamar estuary (UK). In this study, plastic density and beach orientation (up- or downwind) best explained the observed macroplastic distribution, indicating the influence of wind created currents in the distribution of large floating debris. It was hypothesized that, due to their small sizes, microplastics in the water column will behave in the same way as sediment particles. Yet, no clear relationship was observed between microplastic $(<1 \mathrm{~mm})$ abundance and the proportion of clay in the sediment (Browne et al., 2010). It was therefore argued that other processes such as aggregation with organic material might play a more important role in the movement of microplastics. Indeed, Long et al. (2015) demonstrated in a laboratory study that different algae species (Chaetoceros neogracile and Rhodomonas salina) incorporate and concentrate microplastics, substantially increasing microplastic sinking rates. Moreover, Strand et al. (2013) demonstrated that there is a strong relationship between microplastic abundance and both organic (\%TOC) and fine fraction $(<63 \mu \mathrm{m})$ content in sediments, supporting the hypothesis that microplastics will accumulate in depositional areas. In the Lagoon of Venice, Vianello et al. (2013) detected the lowest microplastic concentrations in the outer Lagoon, where water currents are higher $\left(>1 \mathrm{~m} . \mathrm{s}^{-1}\right)$. Consequently, the highest concentrations were encountered in the inner Lagoon which is characterised by lower hydrodynamics and a higher fine particle $(<63 \mu \mathrm{m})$ fraction in the sediment. Aggregation with organic matter (i.e. marine snow) was also considered the main route of transport for microplastics to deep-sea sediments (Van Cauwenberghe et al., 2013b). 
Microplastics are categorised in different classes, based on their overall appearance using simple

299

300

301

302

303

304

305

306

307

308

309

310

311

312

313

314

315

316

317

318

319

320

321

322

323

324

325

326

327

328

329

330

features such as shape, colour, etc. Several categories are used throughout literature, depending on the criteria applied by the authors. Types that re-occur frequently are: pellets, fragments, granules, fibres, films and Styrofoam. Due to their distinctive shape microplastic fibres are easily recognised in environmental samples. As a result, some studies primarily focus on fibres rather than particles (Browne et al., 2011; Browne et al., 2010; Fisher et al., 2015.; Mathalon and Hill, 2014; Thompson et al., 2004). It was demonstrated by Browne et al. (2011) that such fibres are indicative of a sewage origin: an increased microfibre load (> 250\%) was detected in sewage-sludge disposal sites compared to reference sites. As the majority of microplastic fibres were either polyester or acrylic, synthetic garments were considered important sources of microplastics. Browne et al. (2011) investigated the contribution of the use of domestic washing machines and concluded that washing synthetic garments contribute considerable numbers of microplastics to marine environments: up to 1900 fibres can be released into the environment from washing a single piece of clothing.

Microplastics appear to be more abundant in densely populated areas. In a study analysing sediments from 18 locations representing 6 continents, Browne et al. (2011) demonstrated a positive relationship between microplastic and human population density. Indeed, microplastics are detected in large numbers in highly populated areas, such as at locations in the North Sea (Claessens et al., 2011; Liebezeit and Dubaish, 2012; Norén, 2007; Thompson et al., 2004; Van Cauwenberghe et al., 2013a) and the Mediterranean Sea (Kaberi et al., 2013; Klostermann, 2012; Vianello et al., 2013), as well as in Asia (Ismail et al., 2009; Ng and Obbard, 2006; Nor and Obbard, 2014; Reddy et al., 2006) and the highly populated coast of Brazil (Costa et al., 2010; Ivar do Sul et al., 2009; Turra et al., 2014). On heavily polluted beaches, microplastics $(0.25-10 \mathrm{~mm})$ can make up $3.3 \%$ of the sediment by weight, as opposed to $0.12 \%$ plastic by weight on control beaches (Carson et al., 2011). On these Hawaiian beaches, plastics ranging in size from 0.25 to $4 \mathrm{~mm}$ were most abundant (55.5\%), yet proportions of microplastics $(1-4.75 \mathrm{~mm}$ ) of up to $90 \%$ have been reported as well (McDermid and McMullen, 2004). The link between microplastic pollution in sediments and human activities has also been demonstrated by Claessens et al. (2011), who detected particularly high concentrations of microplastic granules in the sediments of coastal harbours. However, as not all types of microplastics could be linked to sources in the harbours, the importance of rivers as potential sources of microplastics to the marine environment was stressed. Recently, this was confirmed by Vianello et al. (2013), who detected the highest microplastic concentrations in those areas influenced most by freshwater inputs. Recently, the importance of rivers as sources of microplastics to the marine environment was demonstrated by Castañeda et al. (2014), who detected high concentrations of 
microbeads in the sediment of the Saint Lawrence river, Canada. These microbeads were suggested to originate from municipal and industrial sewage effluents.

\section{UPTAKE AND EFFECTS IN MARINE ORGANISMS}

As microplastic abundances in the environment increase, organisms inhabiting marine systems are more likely to encounter these particles. Numerous factors such as size, density, shape, charge, colour, aggregation and abundance of the plastic particles affect their potential bioavailability to a wide range of aquatic organisms (Kach and Ward, 2008; Wright et al., 2013a). The opportunity for encountering or uptake of microplastics by marine organisms is mainly attributed to two key properties of the particles: the size and density. For example, particles with a density higher than that of seawater will become available to benthic suspension and deposit feeders (as they sink to the sea floor). As the size fraction of these microplastics is similar (or even smaller) to the grain sizes of sediments, microplastics can be ingested not only by lower trophic-level organisms which capture almost anything of the appropriate size class, but also by other sediment-dwelling organisms (Moore, 2008; Wright et al., 2013a). Consequently, plastic particles may accumulate within these organisms upon ingestion, potentially resulting in direct effects caused by physical injury in the intestinal tract or even translocation to other tissues or organs. Sediment-dwelling organisms are sensitive indicator species for many kinds of naturally and anthropogenically induced disturbances, and are used worldwide as bio-indicators of ecosystem health (OSPAR, 2010; Thain et al., 2008; Van Hoey et al., 2010). Given that this paper deals with the contamination of sediments by microplastics, only species such as echinoderms, polychaetes, crustaceans, bivalves and demersal fish are considered to review the uptake of microplastics and potentially associated effects.

Uptake of microplastics by marine biota has both been investigated in organisms living in natural conditions (Table 3), as well as in laboratory trials (Table 4). Mussels, such as the blue mussel Mytilus edulis is often selected as model species as they inhabit a wide geographic range, are sedentary, and filter large volumes of water. Four recent studies confirmed the contamination of field-collected $M$. edulis with microplastics (Table 3). These studies demonstrated that mussels collected in Europe contained on average 0.2 - 0.5 microplastics/g wet weight (ww) (De Witte et al., 2014; Van Cauwenberghe \& Janssen, 2014; Van Cauwenberghe et al., 2015), while mussels sampled in Canada revealed a much higher microplastic load (34 - 178 microplastics/mussel) (Mathalon and Hill, 2014). Decapod crustaceans, such as Norway lobster (Nephrops norvegicus) and brown shrimp (Crangon crangon), are opportunistic feeders and have been shown to consume plastic present in the natural environment (Table 3). A high prevalence of plastic contamination in Nephrops ( $83 \%$ of investigated individuals) was observed in the Clyde Sea area (Murray and Cowie, 2011). These Nephrops ingested 
plastic strands (attributed to fishing waste), and some individuals were contaminated with tightly tangled balls of synthetic monofilaments. Devriese et al. (in press) noticed that plastic contamination in wild C. crangon mainly consisted of microscopic synthetic fibers at concentrations of $0.64 \pm 0.53$ microplastics/g ww, while only few other types of microplastics were detected in this species. In Gooseneck barnacles (Lepas anatifera and L. pacifica) originating from the North Pacific Subtropical Gyre (NPSG), 33.5\% of individuals had ingested plastic (Goldstein and Goodwin, 2013). The observed plastic contamination in this filter feeder consisted of $99 \%$ degraded fragments and $1 \%$ of monofilament. Controlled lab studies with crustaceans were based on two types of exposure routes: exposure through the surrounding matrix or exposure through contaminated/spiked food items (Table 4). Using seawater spiked with microplastics, lab exposures with barnacles (Semibalanus balanoides) and Carcinus maenas revealed uptake for both crustaceans (Thompson et al., 2004; Watts et al., 2014). In C. maenas, uptake of these microspheres was established through inspiration across the gills. Ingestion due to dietary exposure was established in trials with three different organisms, Carcinus maenas, Nephrops norvegicus and mysid shrimp (Murray and Cowie, 2011; Farrell and Nelson, 2013; Setälä et al., 2013; Watts et al., 2014). N. norvegicus fed with plastic seeded fish revealed the presence of the spiked filaments in the lobsters' stomachs $24 \mathrm{~h}$ following ingestion (Murray and Cowie, 2011). Both Farrell and Nelson (2013) and Watts et al. (2014) confirmed natural trophic transfer of microplastics $(0.5 \mu \mathrm{m}$ and $8-10 \mu \mathrm{m}$, respectively) from mussels ( $M$. edulis) to crab (C. maenas) using pre-exposed mussels. Crabs retained these particles for up to 14 days after ingestion (Watts et al., 2014). Trophic transfer of microplastics from zooplankton to the crustacean Mysis relicta was demonstrated by Setälä et al. (2014) in a laboratory setting using zooplankton preexposed to $10 \mu \mathrm{m}$ spheres (Table 4). After three hours, examination of M. relicta showed a $100 \%$ prevalence of microplastics in the animals' intestine. However, exposure of another mysid species (Mysis mixta) to contaminated prey did not result in microplastic transfer (Setälä et al., 2014). Levels of microplastics in five different demersal fish species from the English Channel were evaluated by Lusher et al. (2013). Overall, 35\% of fish were contaminated with plastic, representing an average environmental microplastic load of $1.90 \pm 0.10$ particles per individual (Table 3). The ingested plastic consisted primarily of fibres, with the most common size class being $1-2 \mathrm{~mm}$. Microplastics ingestion by wild gudgeons (Gobio gobio) from French rivers was also demonstrated (Sanchez et al., 2014). 
Table 3: Microplastic ingestion in the natural environment. Origin of the species investigated is provided (BE: Belgium, NL: the Netherlands, FR: France, UK: United Kingdom, NPSG: North Pacific Subtropical Gyre, CA: Canada, DE: Germany), as well as the particle sizes targeted by the study and extraction protocol (if provided by the authors, otherwise 'unclear').

\begin{tabular}{|c|c|c|c|c|c|c|}
\hline Biota & & Origin & Assay & Microplastic load & $\begin{array}{l}\text { Particle } \\
\text { size }\end{array}$ & Reference \\
\hline Polychaete & $\begin{array}{l}\text { Arenicola } \\
\text { marina }\end{array}$ & $\begin{array}{l}\mathrm{BE}, \\
\mathrm{NL} \\
\mathrm{FR}\end{array}$ & $\begin{array}{c}\text { Whole organism } \mathrm{HNO}_{3} \\
\text { digestion } \\
\text { Faecal analysis }\end{array}$ & $\begin{array}{l}1.2 \pm 2.8 \mathrm{MP} / \mathrm{g} \mathrm{ww} \\
0.3 \pm 0.6 \mathrm{MP} / \mathrm{g} \mathrm{ww}\end{array}$ & $>5 \mu \mathrm{m}$ & $\begin{array}{l}\text { Van Cauwenberghe et } \\
\text { al., } 2015\end{array}$ \\
\hline \multirow{3}{*}{ Crustacea } & $\begin{array}{l}\text { Nephrops } \\
\text { norvegicus }\end{array}$ & UK & Gut analysis & $83 \%$ contained MP & $<5 \mathrm{~mm}$ & Murray \& Cowie, 2011 \\
\hline & $\begin{array}{l}\text { Crangon } \\
\text { crangon }\end{array}$ & $\mathrm{BE}$ & $\begin{array}{c}\text { Whole organism } \\
\mathrm{HNO}_{3}: \mathrm{HClO}_{4}(4: 1 \mathrm{v}: \mathrm{v}) \\
\text { digestion }\end{array}$ & $0.64 \pm 0.53 \mathrm{MP} / \mathrm{g} \mathrm{ww}$ & $>20 \mu \mathrm{m}$ & Devriese et al., in press \\
\hline & Lepas spp. & NPSG & Gut analysis & $33.5 \%$ contained MP & $>0.5 \mathrm{~mm}$ & $\begin{array}{l}\text { Goldstein and } \\
\text { Goodwin, } 2013\end{array}$ \\
\hline \multirow{5}{*}{ Bivalve } & \multirow{4}{*}{ Mytilus edulis } & $\mathrm{BE}$ & $\begin{array}{c}\text { Whole organism } \mathrm{HNO}_{3} \\
\text { digestion }\end{array}$ & $0.36 \pm 0.07 \mathrm{MP} / \mathrm{g}$ ww & $>5 \mu \mathrm{m}$ & $\begin{array}{l}\text { Van Cauwenberghe \& } \\
\text { Janssen, } 2014\end{array}$ \\
\hline & & $\begin{array}{l}B E, \\
F R, \\
N L\end{array}$ & $\begin{array}{c}\text { Whole organism } \mathrm{HNO}_{3} \\
\text { digestion } \\
\text { Faecal analysis }\end{array}$ & $\begin{array}{l}0.2 \pm 0.3 \mathrm{MP} / \mathrm{g} \mathrm{ww} \\
0.1 \pm 0.2 \mathrm{MP} / \mathrm{g} \mathrm{ww}\end{array}$ & $>5 \mu \mathrm{m}$ & $\begin{array}{l}\text { Van Cauwenberghe et } \\
\text { al., } 2015\end{array}$ \\
\hline & & $\begin{array}{c}\text { NL } \\
\text { BE groyne } \\
\text { BE quay }\end{array}$ & $\begin{array}{c}\text { Whole organism } \\
\mathrm{HNO}_{3}: \mathrm{HClO}_{4}(4: 1 \mathrm{v}: \mathrm{v}) \\
\text { digestion }\end{array}$ & $\begin{array}{l}3.5 \text { fibres } / 10 \mathrm{~g} \text { ww } \\
2.6 \text { fibres } / 10 \mathrm{~g} \text { ww } \\
5.1 \text { fibres/10g ww }\end{array}$ & $>20 \mu \mathrm{m}$ & De Witte et al., 2014 \\
\hline & & $\mathrm{CA}$ & $\begin{array}{c}\text { Whole organism } \mathrm{H}_{2} \mathrm{O}_{2} \\
\text { digestion }\end{array}$ & $34-178 \mathrm{MP} /$ ind & $>0.8 \mu \mathrm{m}$ & Mathalon and Hill, 2014 \\
\hline & $\begin{array}{l}\text { Crassostrea } \\
\text { gigas }\end{array}$ & $\mathrm{FR}$ & $\begin{array}{c}\text { Whole organism } \mathrm{HNO}_{3} \\
\text { digestion }\end{array}$ & $0.47 \pm 0.16 \mathrm{MP} / \mathrm{g} w \mathrm{w}$ & $>5 \mu \mathrm{m}$ & $\begin{array}{l}\text { Van Cauwenberghe \& } \\
\text { Janssen, } 2014\end{array}$ \\
\hline \multirow{3}{*}{ Fish } & \multirow{2}{*}{ Demersal fish } & UK & Gut analysis & $1.90 \pm 0.10 \mathrm{MP} /$ ind & unclear & Lusher et al., 2013 \\
\hline & & DE & Gut analysis & $3.4 \%$ contained MP & unclear & Rummel, 2014 \\
\hline & Gobio gobio & FR & Gut analysis & $12 \%$ contained MP & unclear & Sanchez et al., 2014 \\
\hline
\end{tabular}

The blue mussel Mytilus edulis is by far the species used most to study microplastics effect studies. Given that $M$. edulis living in natural habitat takes up microplastics, a number of lab trials have been performed to assess the potential adverse effects of microplastics uptake (Table 4). These, often, short-term effect assays are typically conducted with a single type and/or size of plastic at particle concentrations much higher than realistic environmental levels. Wegner et al. (2012) demonstrated the increased production of pseudofaeces and reduced filter activity after exposure to $30 \mathrm{~nm}$ nanopolystyrene $(0.1,0.2$ and $0.3 \mathrm{~g} / \mathrm{L})$, which according to the authors may lead to increases in the energy expenditure and reduce the organism's food uptake at long term exposure. However, no significant reduction in feeding activity or decrease in energy budget were demonstrated by Browne et al. (2008) and Van Cauwenberghe et al. (2015). Von Moos and co-workers (2012) did observed adverse effects, such as a strong inflammatory response, induced by the uptake of small plastic particles after only 3 hours of exposure (Table 4). Short-term exposure experiments with small polystyrene (PS) spheres (3.0 $\mu \mathrm{m}$ and $9.6 \mu \mathrm{m} ; 1.5 \times 10^{4}$ particles $\left./ 400 \mathrm{~mL}\right)$ and HDPE spheres $(>0-80$ $\mu \mathrm{m} ; 2.5 \mathrm{~g} / \mathrm{L}$ ) revealed their translocation (especially of smaller microspheres) from the digestive tract 
to the circulatory system and digestive cells of M. edulis (Browne et al., 2008; Von Moos et al., 2012). Translocation of microplastics after ingestion was also demonstrated for the crab Carcinus maenas (Farrell and Nelson, 2013). Using pre-exposed mussels, this study demonstrated the translocation of small microplastics to the hemolymph of the crabs after indirect exposure, i.e. exposure through contaminated prey. In a similar setup, however, Watts et al. (2014) did find any indications of translocation to the hemolymph in exposed crabs. An important sediment-associated marine organisms that has been the subject of several microplastic effect assessments is the lugworm Arenicola marina (Table 4). In a short-term exposure (14 days) experiment, lugworms were exposed to sediment spiked with $10 \mu \mathrm{m}, 30 \mu \mathrm{m}$ and $90 \mu \mathrm{m}$ PS spheres (total concentration of 100 particles. $\mathrm{g}^{-1}$ sediment). While these short-term exposure did not demonstrate a significant effect on the energy metabolism (Van Cauwenberghe et al., 2015), mid-term trials (28 days) revealed clear severe effects (Wright et al., 2013b). After 28 days of exposure to 5\% by weight unplasticised PVC (mean diameter $130 \mu \mathrm{m})$, a significant decrease in body weight and a significant reduction of the feeding activity was observed, which was ultimately reflected by a depletion of up to $50 \%$ of the energy reserves (Wright et al., 2013b).

Regrettably, due to the lack of consistency in the assays used and technical challenges (e.g. difficulties in dissecting invertebrates), environmental levels of microplastics in invertebrate organisms are difficult to interpret. As a result, intra- and interspecies evaluation is very difficult. The most common discrepancies can be related to the organ or tissues examined, the extraction protocol (e.g. digestion of tissues), the risk of airborne contamination (Woodall et al., 2015), the particle size range assessed, the reporting unit and the identification of plastics (Song et al., 2015). For example, hot acid digestion using $\mathrm{HNO}_{3}(69 \%)$ was proposed by Claessens et al. (2013), while an adaptation using a 4:1 (v:v) mixture of nitric acid $\left(65 \% \mathrm{HNO}_{3}\right)$ and perchloric acid $\left(68 \% \mathrm{HClO}_{4}\right)$ was used by Devriese et al. (in press). Furthermore, Mathalon and Hill (2014) used an oxidizing agent $\left(30 \% \mathrm{H}_{2} \mathrm{O}_{2}\right)$ to remove animal tissue. Besides the digestion assay, the particle retention of the used filters to filtrate the digest outlines the observed particle size range. For this reason Mathalon and Hill (2014) assessed microplastics $>0.8 \mu \mathrm{m}$, Van Cauwenberghe and Janssen (2014) >5 $\mu \mathrm{m}$, while De Witte et al. (2014) evaluated microplastics $>20 \mu \mathrm{m}$. 
Table 4: Direct effects of microplastic exposure to aquatic (benthic) organisms, demonstrated under controlled laboratory conditions. Details on the exposure conditions, i.e. exposure route, particle type and size (if provided by the authors) and exposure concentration, are provided. (UPVC: unplasticised polyvinylchloride, PS: polystyrene, HDPE: highdensity polyethylene).

\begin{tabular}{|c|c|c|c|c|c|c|c|}
\hline Biota & & $\begin{array}{l}\text { Exposure } \\
\text { route }\end{array}$ & Particle type & $\begin{array}{l}\text { Exposure } \\
\text { concentration }\end{array}$ & Assay & Effect & Reference \\
\hline \multirow{5}{*}{ Polychaete } & \multirow{5}{*}{$\begin{array}{l}\text { Arenicola } \\
\text { marina }\end{array}$} & $\begin{array}{l}\text { Spiked } \\
\text { sediment }\end{array}$ & $\begin{array}{l}125-150 \mu \mathrm{m} \\
\text { UPVC }\end{array}$ & $5 \%$ by weight & $\begin{array}{l}\text { Energy budget } \\
\text { Feeding activity }\end{array}$ & $\begin{array}{l}\text { Decreases in } \\
\text { energy budget } \\
\text { and feeding }\end{array}$ & $\begin{array}{l}\text { Wright et al., } \\
2013 b\end{array}$ \\
\hline & & $\begin{array}{l}\text { Spiked } \\
\text { sediment }\end{array}$ & $20-2000 \mu \mathrm{m}$ & $1.5 \mathrm{~g} \mathrm{MP} / \mathrm{L}$ & Faecal analysis & Ingestion & $\begin{array}{l}\text { Thompson et al., } \\
2004\end{array}$ \\
\hline & & \multirow{3}{*}{$\begin{array}{l}\text { Spiked } \\
\text { sediment }\end{array}$} & $10 \mu \mathrm{m}$ PS & $50 \mathrm{MP} / \mathrm{mL}$ & \multirow{3}{*}{ Energy budget } & \multirow{3}{*}{$\begin{array}{l}\text { No significant } \\
\text { effect }\end{array}$} & \multirow{3}{*}{$\begin{array}{l}\text { Van } \\
\text { Cauwenberghe } \\
\text { et al., } 2015\end{array}$} \\
\hline & & & $30 \mu \mathrm{m}$ PS & & & & \\
\hline & & & $90 \mu \mathrm{m}$ PS & $10 \mathrm{MP} / \mathrm{mL}$ & & & \\
\hline \multirow{8}{*}{ Crustacea } & \multirow[t]{2}{*}{ Mysis spp. } & $\begin{array}{l}\text { Spiked } \\
\text { seawater }\end{array}$ & \multirow[t]{2}{*}{$10 \mu \mathrm{m}$ PS } & $\begin{array}{l}1,000 \mathrm{MP} / \mathrm{mL} \\
2,000 \mathrm{MP} / \mathrm{mL}\end{array}$ & \multirow[t]{2}{*}{ Ingestion } & $\begin{array}{l}\text { Ingestion } \\
\text { No } \\
\text { accumulation }\end{array}$ & \multirow{2}{*}{$\begin{array}{l}\text { Setälä et al., } \\
2014\end{array}$} \\
\hline & & $\begin{array}{l}\text { Pre-exposed } \\
\text { zooplankton }\end{array}$ & & $10,000 \mathrm{MP} / \mathrm{mL}$ & & Trophic transfer & \\
\hline & \multirow{4}{*}{$\begin{array}{l}\text { Carcinus } \\
\text { maenas }\end{array}$} & Spiked & \multirow{3}{*}{$8-10 \mu \mathrm{m}$ PS } & $9.4 \times 10^{5} \mathrm{MP} / \mathrm{L}$ & & \multirow{3}{*}{ Retention } & \multirow{3}{*}{$\begin{array}{l}\text { Watts et al., } \\
2014\end{array}$} \\
\hline & & seawater & & $4.0 \times 10^{4} \mathrm{MP} / \mathrm{L}$ & Tissue analysis & & \\
\hline & & $\begin{array}{l}\text { Spiked } \\
\text { mussels }\end{array}$ & & $4.0 \times 10^{3} \mathrm{MP} / \mathrm{g}$ & Faecal analysis & & \\
\hline & & $\begin{array}{l}\text { Pre-exposed } \\
\text { mussels }\end{array}$ & $0.5 \mu \mathrm{m}$ PS & & Tissue analysis & $\begin{array}{l}\text { Translocation } \\
\text { Trophic transfer }\end{array}$ & $\begin{array}{l}\text { Farrell and } \\
\text { Nelson, } 2013\end{array}$ \\
\hline & $\begin{array}{l}\text { Semibalanus } \\
\text { balanoides }\end{array}$ & $\begin{array}{l}\text { Spiked } \\
\text { seawater }\end{array}$ & $20-2000 \mu \mathrm{m}$ & $1 \mathrm{~g} / \mathrm{L}$ & Gut analysis & Ingestion & $\begin{array}{l}\text { Thompson et al., } \\
2004\end{array}$ \\
\hline & $\begin{array}{l}\text { Nephrops } \\
\text { norvegicus }\end{array}$ & Spiked fish & $5 \mathrm{~mm} \mathrm{PP}$ & 10 fibres $/ \mathrm{cm}^{3}$ & $\begin{array}{l}\text { Stomach } \\
\text { analysis }\end{array}$ & $\begin{array}{l}\text { Retention } \\
\text { Accumulation }\end{array}$ & $\begin{array}{l}\text { Murray \& Cowie, } \\
2011\end{array}$ \\
\hline \multirow{9}{*}{ Bivalve } & \multirow{8}{*}{ Mytilus edulis } & $\begin{array}{l}\text { Spiked } \\
\text { seawater }\end{array}$ & $\begin{array}{l}3.0 \mu \mathrm{m} \text { PS } \\
9.6 \mu \mathrm{m} \text { PS }\end{array}$ & $\begin{array}{l}15,000 \mathrm{MP} / 400 \\
\mathrm{~mL}\end{array}$ & $\begin{array}{l}\text { Gut and } \\
\text { hemolymph } \\
\text { analysis }\end{array}$ & $\begin{array}{l}\text { Translocation to } \\
\text { circulatory } \\
\text { system }\end{array}$ & $\begin{array}{l}\text { Browne et al., } \\
2008\end{array}$ \\
\hline & & Spiked & $10 \mu \mathrm{m}$ PS & $50 \mathrm{MP} / \mathrm{mL}$ & \multirow{3}{*}{ Energy budget } & \multirow{3}{*}{$\begin{array}{l}\text { No significant } \\
\text { effect }\end{array}$} & \multirow{3}{*}{$\begin{array}{l}\text { Van } \\
\text { Cauwenberghe } \\
\text { et al., } 2015\end{array}$} \\
\hline & & seawater & $30 \mu \mathrm{m}$ PS & & & & \\
\hline & & seavalet & $90 \mu \mathrm{m}$ PS & $10 \mathrm{MP} / \mathrm{mL}$ & & & \\
\hline & & $\begin{array}{l}\text { Spiked } \\
\text { seawater }\end{array}$ & $\begin{array}{l}>0-80 \mu \mathrm{m} \\
\text { HDPE }\end{array}$ & $2.5 \mathrm{~g} / \mathrm{L}$ & $\begin{array}{l}\text { Histological and } \\
\text { histochemical } \\
\text { assays }\end{array}$ & $\begin{array}{l}\text { Accumulation in } \\
\text { lysosomal } \\
\text { system and } \\
\text { digestive cells } \\
\text { Inflammatory } \\
\text { response }\end{array}$ & $\begin{array}{l}\text { Von Moos et al., } \\
2012\end{array}$ \\
\hline & & $\begin{array}{l}\text { Spiked } \\
\text { seawater }\end{array}$ & $30 \mathrm{~nm}$ PS & $\begin{array}{l}0.1 \mathrm{~g} / \mathrm{L} \\
0.2 \mathrm{~g} / \mathrm{L} \\
0.3 \mathrm{~g} / \mathrm{L}\end{array}$ & Feeding activity & $\begin{array}{l}\text { Pseudofaeces } \\
\text { production } \\
\text { Reduced feeding }\end{array}$ & $\begin{array}{l}\text { Wegner et al., } \\
2012\end{array}$ \\
\hline & & $\begin{array}{l}\text { Spiked } \\
\text { seawater }\end{array}$ & $\begin{array}{l}0.5 \mu \mathrm{m} \\
1 \mu \mathrm{m}\end{array}$ & $12,000 \mathrm{MP} / \mathrm{mL}$ & Ingestion rate & $\begin{array}{l}\text { (Aggregate) } \\
\text { Ingestion }\end{array}$ & $\begin{array}{l}\text { Kach and Ward, } \\
2008\end{array}$ \\
\hline & & $\begin{array}{l}\text { Spiked } \\
\text { seawater }\end{array}$ & $100 \mathrm{~nm}$ & $13,000 \mathrm{MP} / \mathrm{mL}$ & Ingestion rate & Ingestion & $\begin{array}{l}\text { Ward and Kach, } \\
2009\end{array}$ \\
\hline & $\begin{array}{l}\text { Crassostrea } \\
\text { virginica }\end{array}$ & $\begin{array}{l}\text { Spiked } \\
\text { seawater }\end{array}$ & $100 \mathrm{~nm}$ & $13,000 \mathrm{MP} / \mathrm{mL}$ & Ingestion rate & Ingestion & $\begin{array}{l}\text { Ward and Kach, } \\
2009\end{array}$ \\
\hline \multirow{4}{*}{ Echinoderm } & \multirow{3}{*}{ Holothuria } & \multirow{3}{*}{$\begin{array}{l}\text { Spiked } \\
\text { sediment }\end{array}$} & $0.25-15 \mathrm{~mm}$ & $10 \mathrm{~g}$ & \multirow{3}{*}{ Ingestion rate } & \multirow{3}{*}{$\begin{array}{l}\text { Selective } \\
\text { ingestion }\end{array}$} & \multirow{3}{*}{$\begin{array}{l}\text { Graham and } \\
\text { Thompson, } 2009\end{array}$} \\
\hline & & & PVC & $65 g$ & & & \\
\hline & & & $\begin{array}{l}0.25-1.5 \mathrm{~mm} \\
\text { Nylon }\end{array}$ & $2 g$ & & & \\
\hline & $\begin{array}{l}\text { Paracentrotus } \\
\text { lividus }\end{array}$ & $\begin{array}{l}\text { Spiked } \\
\text { seawater }\end{array}$ & $50 \mathrm{~nm}$ PS & $\begin{array}{l}3 \mu \mathrm{g} / \mathrm{mL} \\
25 \mu \mathrm{g} / \mathrm{mL}\end{array}$ & $\begin{array}{l}\text { Embryotoxicity } \\
\text { Gene expression }\end{array}$ & $\begin{array}{l}\text { Developmental } \\
\text { defects }\end{array}$ & $\begin{array}{l}\text { Della Torre et al., } \\
2014\end{array}$ \\
\hline
\end{tabular}


The published microplastics effect assessments are typically conducted with only one type or size of plastic (mostly microspheres) at particle concentrations much higher than the environmental levels. Strikingly, all the lab trials are based on short- to mid-term (hours to 28 days) exposure to unrealistically high concentrations. These papers revealed a range of effects exhibited ingestion by a number of species, e.g. decrease of energy reserves, inhibition or reduction of feeding/filtering activity, translocation to the circulatory system, inflammatory response and developmental defects. A few papers observed trophic transfer of microplastics and suggest an impact on the food web. Although more research is needed to determine whether plastics of any dimensions can be transferred through the food chain, translocation effects do suggest that particle size really matters. For evaluating the environmental risk of microplastics knowledge is required on the environmental levels and types of plastic, the translocation size limit and the relevant biological endpoints. Additionally, long-term exposures under controlled conditions with environmentally relevant microplastics concentrations and types are needed to allow a realistic assessment of potential microplastic-associated risks.

\section{Indirect effects}

Due to their specific characteristics, microplastics not only pose a direct threat to (marine) organisms, but they are also believed to have indirect effects on organisms. We define indirect effects as an effect caused when microplastics act as a vector for either chemicals (i.e. chemical threat) or bacteria (i.e. bacterial threat).

The chemical threat of microplastic is complex and works at different levels. Plastic polymers, owing to their large size, are considered to be biochemically inert. However, as polymerization reactions are rarely complete, residual monomers can still be found in the polymer matrix. Residual monomer content of a plastic can vary from $0.0001 \%$ to $4 \%$ (Araújo et al., 2002). These monomers can leach out of the polymeric material and, as some of these are considered toxic (including carcinogenic and mutagenic effects), they can pose a threat to the environment. This effect can be estimated based on the monomer hazard ranking as described by Lithner (2011). Most hazardous polymers belong to the families of polyurethanes, polyvinyl chloride and styrene, amongst others (Lither, 2011). Additional toxic effects of microplastics can also be caused by the wide array of plastic additives added during plastic manufacturing. Examples are the initiators, catalysts and solvents, all of which are added to obtain specific features of the final polymer. But also antimicrobial agents, such as Triclosan, plasticisers, flame retardants (PBDEs), pigments and fillers are used in the compounding of plastic. All these non-polymeric components are of low molecular weight and 
therefore able to migrate or diffuse from the plastic polymer, potentially causing (adverse) effects (Crompton, 2007).

This migration behaviour is similar for chemical contaminants (POPs) adsorbed on microplastics. It is known that a plethora of persistent organic pollutants (POPs) can sorb from the environment (i.e. seawater and sediment) on/in the plastic matrix of (micro)plastics. The presence of such POPs on marine plastics (especially industrial resin pellets) has been demonstrated for a wide variety of chemicals and for different geographic areas (e.g. Mato et al., 2001; Endo et al., 2005; Hirai et al., 2011; Bakir et al., 2014) (see Table 1 for additional studies on contaminant assessment on industrial resin pellets). These contaminants have a greater affinity for the plastic matrix than the surrounding seawater leading to an accumulation onto the plastic particle. This accumulation was found to be up to one million times higher in some cases (Hirai et al., 2011). Polymer type plays an important role in this contamination accumulation: under identical sorption conditions, polychlorinated biphenyls (PCBs) and polycyclic aromatic hydrocarbons (PAHs) are consistently found in a higher concentration on high-density polyethylene (HDPE), low-density polyethylene ( LDPE) and polypropylene (PP), compared to polyethylene terephthalate (PET) and polyvinyl chloride (PVC), while phenanthrene sorbs more to PE than PP or PVC (Bakir et al., 2012; Rochman et al., 2013; Bakir et al., 2014). As a result, possible effects of both the polymer and associated contaminants have to be considered when assessing the potential risks of microplastics.

Although frequently suggested, the evidence to support this chemical threat is rather limited. So far controlled lab exposures have been performed with the lugworm (Arenicola marina), the model organism for deposit feeders. Exposure of A. marina to PCB-loaded microplastics (at a dose of $7.4 \%$ microplastics by dry weight) showed an effect on feeding activity, resulting in weight loss (Besseling et al., 2013). Browne et al. (2013) demonstrated a decreased phagocytic activity by over $60 \%$ in $A$. marina exposed to sand with 5\% microplastic (PVC, $230 \mu \mathrm{m}$ ) presorbed with nonylphenol. However, no such effect was reported for phenanthrene. While nonylphenol and phenanthrene desorbed from the PVC particles and transferred to the animals' tissue, the lugworms accumulated $>250 \%$ more of these contaminants when exposed to contaminated sand (Browne et al., 2013).

The bioaccumulation of persistent organic pollutants (POPs) has been theoretically investigated by Gouin et al. (2011) and Koelmans et al. (2013) using a modelling approach. Both studies suggested that microplastics are only of minor importance as vectors of POPs to organisms. Koelmans et al. (2013) even predicted a decrease in contaminant body burden due to a cleaning mechanism of strong sorbent plastics, counteracting biomagnification. In a similar modelling exercise, Koelmans et al. (2014) investigated the leaching of plastic associated chemicals, i.e. 
additives, to marine organisms. The rationale behind this modelling approach is the fact that for additives plastic ingestion by marine organisms may be more relevant than for diffusely spread POPs as the microplastics act as a source of the additives (Koelmans et al., 2014). The results showed that ingestion of microplastics can be considered a substantial pathway for additive exposure. It is clear that further research on this topic is essential to fully understand the impact of sorbed and plasticassociated contaminants on marine organisms, and by extension the entire marine and human food web. So far, studies to assess the transfer of (environmentally relevant concentrations of) chemicals, both pollutants and additives, have not been performed on resident organisms, clearly indicating that this is an area that needs further research.

The bacterial threat of marine litter and by extension microplastics arises from the fact that they represent new habitats in the marine environment and, as such, can serve as a substrate for (micro)biological interactions. Microplastics have a hydrophobic surface that stimulates rapid biofilm formation (Zettler, 2013). So far, conventional microbial identification methodologies require a bacterial cultivation step using a growth medium, has hampered the full characterization of the microbial biofilm due to the 'great plate count anomaly' (Staley, 1985). This term has been used to describe the fact that the majority (99-99.9\%) of cells within an environmental sample are not recoverable in pure culture using classical microbial plating. However, the recent breakthrough of 'Next Generation Sequencing' technology allows for the full characterization of complex microbial samples without a cultivation step. This was nicely demonstrated in the pioneering work of Zettler et al. (2013) and will contribute significantly to biofilm characterization.

Due to their persistence in nature, (micro)plastics exhibit a longer half life than other marine substrates, creating an interesting habitat for microorganisms. For fouling, microbial biofilm formation is the initial step (Dobretsov, 2010), while in the consecutive steps so-called epiplastic organism like diatoms, ciliates and a wide variety of other organisms will attach on the formed biofilm (Reisser et al., 2014a). The formation of these biofilms on microplastics is of concern as they might contain human or animal pathogens that could potentially endanger animal and human health, and impact economic activities. Additionally, the nutritional value of these biofilms might encourage grazing and ingestion of the covered microplastics (Reisser et al., 2014b). Associated impacts hence include food web effects.

In 2011, Harrison et al. published a call for research, calling upon the scientific community to investigate the colonisation, taxonomic composition and functional potential of microplasticassociated biofilms, in order to understand ecological implications and to develop management measures to safeguard marine life. As a response, research started focussing on characterizing the 
microbial assemblages of floating microplastic particles (Carson et al., 2013b; Reisser et al., 2014a; Zettler et al., 2013). Carson et al. (2013) investigated the biofilms of 100 particles (1-10 mm) collected in the Northeast Pacific, and determined that plastic type appeared to influence bacteria abundance. Zettler et al. (2013) discovered that microplastic-associated communities differ significantly from those in the surrounding seawater. For example, several hydrocarbon degraders were detected on the plastic but not in the seawater, indicating microorganisms may possibly play a role in plastic degradation (Zettler et al., 2013). Colonisation and biofilm characterisation of microplastics in marine sediments has been far less investigated. Harrison et al. (2014) used a coastal sediment microcosm and demonstrated that bacteria in marine sediments rapidly colonise low density polyethylene (LDPE) microplastic fragments $(5 \mathrm{~mm})$. As was the case for seawater (Zettler et al., 2013), the bacterial communities detected on the plastic were significantly different from those in the surrounding sediment. Interestingly, the dominant taxa (Acrobacter and Colwellia spp.) on microplastics from sediments were not found to be present on floating microplastics, indicating that distinct biofilms are likely to occur between different marine habitat types (Harrison et al., 2014).

\section{CONCLUSIONS AND OUTLOOK}

Important advances have been made with respect to our understanding of the occurrence and impacts of microplastics in marine environment. However, as this research field is rapidly evolving, especially in the last 10 years as is reflected in the exponential growth of peer-reviewed publications, several issues can be identified regarding the nomenclature and classification of microplastics and applied methodologies and techniques. The current lack in standardisation and harmonisation greatly hampers the inter-study comparison and data transfer, not only for reported abundances but also for (measured) effects and impacts. We therefore recommend the implementation of a unequivocal size-based definition for microplastics, based on both upper and lower size limits, and a uniform nomenclature. Also practical issues concerning the assessment of occurrence and effects should be addressed and standardised. Today, a plethora of sampling, extraction and identification techniques are in use. An important point of interest is the harmonisation of extraction techniques. While the majority of extraction techniques are based on the same principle, i.e. density separation, a wide assortment of variations on this principle exist. Some are more efficient in extracting different types of microplastics (i.e. differences in density) than others, but in some cases this comes at an extra cost. It is clear that a standard extraction technique, especially for monitoring purposes, should be adopted by the research and regulatory community. In general, depending on the research question addressed, sampling strategies will differ. Yet, by reporting the complete set of sampling details (i.e. sampling depth, sediment weight or volume, but also sediment density, water content, 
etc.) differences between sampling techniques can be bypassed, and inter-study comparison facilitated. As such, this proposed harmonisation will assist future, uniform microplastic abundance assessments, and allow science-based geographical comparison and time trend assessments.

A general conclusion regarding the assessment of potential (adverse) effects following microplastic uptake in marine organisms concerns the experimental set-up of such experiments. In general, experimental microplastic concentrations are several orders of magnitude higher than current environmental concentrations, and all lab trial exposure periods are short- to mid term. While such approaches are often performed using 'proof of principle' experiments, and deemed necessary to assess the importance of this type of pollution, testing at high, environmentally unrealistic, concentrations does not provide any information on the current adverse effects on or risks to marine ecosystems. Future effect assessments of microplastics should therefore focus on mimicking more 'natural' exposure conditions. More specifically, there is a need for more long-term exposure assessments of environmentally relevant concentrations of naturally occurring assemblages of microplastics (i.e. different sizes, shapes and types).

The chemical threat of microplastics has been studied elaborately in the past years, raising some concerns. While adverse biological effects have been measured in the lab, some studies suggest (small) microplastics play only a minor part in the total body load of such environmental contaminants in marine organisms. While there is a growing body of literature regarding pollutants on microplastics, additives, or plastic-associated chemicals, are far less studied. Yet, due to the lower concentrations of these additives in the environment, transfer of these chemicals from microplastics to organisms might be more relevant than the sorbed chemicals. However, it is clear that further research on this topic is essential to fully understand the impact of sorbed and plastic-associated contaminants on marine organisms, and by extension the entire marine, and human, food web.

A far less researched potential threat of microplastics, is the presence and transfer of (potentially harmful) marine microorganisms associated with these plastics. To date, only limited literature is available on microplastic biofilm characterisation. We need to understand the colonisation dynamics and taxonomic composition (more specifically the presence and transport of pathogens and other harmful species) to properly assess the ecological implications, as these organisms could result in ecological and economical consequences to the marine food webs and human health. 


\section{ACKNOWLEDGEMENT}

614 Lisbeth Van Cauwenberghe is the recipient of a Ph.D. grant of the Agency for Innovation by 615 Science and Technology (IWT, Belgium). 
617

618

619

620

621

622

623

624

625

626

627

628

629

630

631

632

633

634

635

636

637

638

639

640

641

642

643

644

645

646

647

648

ABU-HILAL, A.H., AL-NAJJAR, T.H., 2009. Plastic pellets on the beaches of the Northern Gulf of Aqaba, Red Sea. Aquatic Ecosystem Health and Management 12, 461-470. doi: 10.1080/14634980903361200.

ANDRADY, A.L., 2011. Microplastics in the marine environment. Marine Pollution Bulletin 62, 1596 1605. doi: 10.1016/j.marpolbul.2011.05.030.

Andrady, A.L., NeaL, M.A., 2009. Applications and societal benefits of plastics. Philosophical Transactions of the Royal Society B-Biological Sciences 364, 1977-1984. doi: 10.1098/rstb.2008.0304.

ANTUNES, J.C., FriAS, J.G.L., MicAeLO, A.C., SobraL, P., 2013. Resin pellets from beaches of the Portuguese coast and adsorbed persistent organic pollutants. Estuarine Coastal and Shelf Science 130, 62-69. doi: 10.1016/j.ecss.2013.03.016.

ARAÚJo, P.H.H., SAYER, C., Poco, J.G.R., GIUDICI, R., 2002. Techniques for reducing residual monomer content in polymers: a review. Polymer Engineering and Science, 42, 1442-1468. doi: 10.1002/pen.11043.

ARTHUR, C., BAKER, J., BAMFORD, H., 2009. Proceedings of the International research Workshop on the Occurence, Effects and Fate of Microplastic Marine Debris. NOAA Technical Memorandum NOS-OR\&R-30, pp. 49,

ASHTON, K., HOLmeS, L.A., TURner, A., 2010. Association of metals with plastic production pellets in the marine environment. Marine Pollution Bulletin 60, 2050-2055. doi: 10.1016/j.marpolbol.2010.07.014.

BAKIR, A., ROWLAND, S.T., THOMPSON, R.C., 2012. Competitive sorption of persistent organic pollutants onto microplastics in the marine environment. Marine Pollution Bulletin 64, 2782-2789. doi: 10.1016/j.marpolbul.2012.09.010.

BAKIR, A., ROWLAND, S.J., THOMPSON, R.C., 2014. Enhanced desorption of persistent organic pollutants from microplastics under simulated physiological conditions. Environmental Pollution 185, 16-23. doi: http://dx.doi.org/10.1016/j.envpol.2013.10.007.

BAllent, A., PuRSER, A., De Jesus Mendes, P.P., S., Thomsen, L., 2012. Physical transport properties of marine microplastic pollution. Biogeosciences Discussions 9, 18755-18798. doi: 10.5194/bgd9-18755-2012.

BARNES, D.K.A., GALGANI, F., ThOMPSON, R.C., BARLAZ, M., 2009. Accumulation and fragmentation of plastic debris in global environments. Philosophical Transactions of the Royal Society BBiological Sciences 364, 1985-1998. doi: 10.1098/rstb.2008.0205. 
Baztan, J., Carrasco, A., Chouinard, O., Cleaud, M., Gabaldon, J.E., Huck, T., Jaffrès, L., Jorgensen, B., Miguelez, A., Paillard, C., Vanderlinden, J.-P., 2014. Protected areas in the Atlantic facing the hazards of micro-plastic pollution: First diagnosis of three islands in the Canary Current. Marine Pollution Bulletin 80, 302-311. doi: 10.1016/j.marpolbul.2013.12.052.

Besseling, E., Wegner, A., Foekema, E.M., Van Den Heuvel-Greve, M., Koelmans, A.A., 2013. Effects of microplastic on fitness and PCB bioaccumulation by the lugworm Arenicola marina (L.). Environmental Science \& Technology 47, 593-600. doi: 10.1021/es302763x.

Browne, M.A., Dissanayake, A., Galloway, T.S., LoWe, D.M., Thompson, R.C., 2008. Ingested microscopic plastic translocates to the circulatory system of the mussel, Mytilus edulis (L.). Environmental Science \& Technology 42, 5026-5031. doi: 10.1021/es800249a.

Browne, M.A., Crump, P., Niven, S.J., Teuten, E., Tonkin, A., Galloway, T.S., Thompson, R.C., 2011. Accumulation of microplastic on shorelines worldwide: Sources and sinks. Environmental Science \& Technology 45, 9175-9179. doi: 10.2021/es201811s.

Browne, M.A., Galloway, T.S., Thompson, R.C., 2010. Spatial Patterns of Plastic Debris along Estuarine Shorelines. Environmental Science \& Technology 44, 3404-3409. doi: 10.1021/es903784e.

Browne, M.A., Niven, S.J., Galloway, T.S., Rowland, S.J., ThOMPSON, R.C., 2013. Microplastic moves pollutants and additives to worms, reducing functions linked to health and biodiversity. Current Biology 23, 2388-2392. doi: 10.1016/j.cub.2013.10.012.

CARPenter, E.J., Anderson, S.J., Harvey, G.R., MiKLAS, H.P., PeCK, B.B., 1972. Polystyrene Spherules in Coastal Waters. Science 178, 749-750. doi: 10.1126/science.178.4062.749.

CARPENTER, E.J., SMITH, K.L., 1972. Plastics on the Sargasso Sea Surface. Science 175, 1240-1241. doi: 10.1126/science.175.4027.1240.

CARSon, H.S., ColberT, S.L., KAYLOR, M.J., McDeRMID, K.J., 2011. Small plastic debris changes water movement and heat transfer through beach sediments. Marine Pollution Bulletin 62, 17081713. doi: 10.1016/j.marpolbul.2011.05.032.

Carson, H.S., Lamson, M.R., Nakashima, D., Toloumu, D., Hafner, J., Maximenko, N.A., McDermid, K.J., 2013a. Tracking the sources and sinks of local marine derbis in Hawai'i. Marine Environmental Research 84, 76-83. doi: 10.1016/j.marenvres.2012.12.002.

CARSON, H.S., NerHeIM, M.S., CARROlL, K.A., ERIKSEN, M., 2013. The plastic-associated microorganisms of the North Pacific Gyre. Marine Pollution Bulletin 5, 126-132. doi: 10.1016/j;marpolbul.2013.07.054.

CAstañeda, R.A., Avlijas, S., Simard, M.A., Ricciardi, A., 2014. Microplastic pollution in St. Lawrence River sediments. Canadian Journal of Fisheries and Aquatic Sciences 70, 1767-1771. doi: 10.1139/cjfas-2014-0281. 
Claessens, M., De Meester, S., Van Landuyt, L., De Clerck, K., Janssen, C.R., 2011. Occurence and distribution of microplastics in marine sediments along the Belgian coast. Marine Pollution Bulletin 62, 2199-2204. doi: 10.1016/j.marpolbul.2011.06.030.

Claessens, M., Van Cauwenberghe, L., Vandegehuchte, M.B., Janssen, C.R., 2013. New techniques for the detection of microplastics in sediments and field collected organisms. Marine Pollution Bulletin 70, 227-233. doi: 10.1016/j.marpolbul.2013.03.009.

Cole, M., Lindeque, P., HALSBAnd, C., Galloway, T.S., 2011. Microplastics as contaminants in the marine environment: A review. Marine Pollution Bulletin 62, 2588-2597. doi: 10.1016/j.marpolbul.2011.09.025.

Costa, M.F., IVAR do Sul, J.A., Silva-Cavalcanti, J.S., Araúja, M.C.B., SPengler, A., Tourinho, P.S., 2010. On the importance of size of plastic fragments and pellets on the strandline: a snapshot of a Brazilian beach. Environmental Monitoring and Assessment 168, 299-304. doi: 10.1007/s10661-009-1113-4.

Costa, M.F., Silva-Cavalcanti, J.S., Barbosa, C.C., Portugal, J.L., Barletta, M., 2011. Plastics buried in the inter-tidal plain of a tropical estuarine ecosystem. Journal of Coastal Research SI 64, 339343.

Cózar, A., Echevarria, F., Gonzalez-Gordillo, J.I., Irigoien, X., Úbeda, B., Hernández-LÉon, S., Palma, A.T., NAvarro, S., García-de-Lomas, J., Ruiz, A., Fernández-de-Puelles, M.L., Duarte, C.M., 2014. Plastic debris in the open ocean. PNAS 111, 10239-10244. doi: 10.1073/pnas.1314705111.

CROMPTON, T.R., 2007. Additive migration from plastic into food: A guide for the Analytical Chemist. Smithers Rapra Technology Limited, Shawsbury, Shrewbury, Shropshire, 312 pp.

DEKIFF, J.H., REMY, D., KLASMEIER, J., FRIES, E., 2014. Occurence and spatial distribution of microplastics in sediments from Norderney. Environmental Pollution 186. doi: 10.1016/j.envpol.2013.11.019.

Della Torre, C., Bergami, E., Salvati, A., Faleri, C., Cirino, P., Dawson, K.A., Corsi, I. 2014. Accumulation and embryotoxicity of polystyrene nanoparticles at early stage of development of sea urchin embryos Paracentrotus lividus. Environmental Science \& Technology 48, 12302-11. doi: $10.1021 /$ es502569w.

De Witte, B., Devriese, L., Bekaert, K., Hoffman, S., Vandermeersch, G., Cooreman, K., Robbens, J., 2014. Quality assessment of the blue mussel (Mytilus edulis): Comparison between commercial and wild types. Marine Pollution Bulletin 85, 146-155. doi: 10.1016/j.marpolbul.2014.06.006.

Devriese, L., van der Meulen, M.D., Maes, T., Bekaert, K., Paul-Pont, I., Lambert, C., Huvet, A., Soudant, P., ROBBEnS, J., VeTHAAK, A.D., in press. Evaluation of the ingested microplastics content in European brown shrimp (Crangon crangon, Linnaeus 1758). Marine Pollution Bulletin. 
DoBRETSOV, S., 2010. Marine biofilms. In: Dürr, S., Thomason, J.C. (Eds.), Biofouling. Wiley-Blackwell, Chichester, pp. 123-136.

Endo, S., Takizawa, R., OKuda, K., TAKada, H., Chiba, K., Kanehiro, H., Ogl, H., Yamashita, R., Date, T., 2005. Concentration of polychlorinated biphenyls (PCBs) in beached resin pellets: Variability among individual particles and regional differences. Marine Pollution Bulletin 50, 1103-1114. doi: 10.1016/j.marpolbul.2005.04.030.

EPA, 1992. Plastic Pellets in the Aquatic Environment: Sources and Recommendations. Final Report. US EPA Oceans and Coastal Protection Division, pp. 117.

Eriksen, M., Mason, S., Wilson, S., Box, C., Zellers, A., EdWARds, W., Farley, H., Amato, S., 2013. Microplastic pollution in the surface waters of the Laurentian Great Lakes. Marine Pollution Bulletin 77, 177-182. doi: 10.1016/j.marpolbul.2013.10.007.

Eriksen, M., Lebreton, L.C.M., Carson, H.S., Thiel, M., Moore, C.J., Borerro, J.C., Galgani, F., Ryan, P.G., REISSER, J. 2014. Plastic Pollution in the World's Oceans: More than 5 Trillion Plastic Pieces Weighing over 250,000 Tons Afloat at Sea. PLOS ONE 9: e111913. doi: 10.1371/journal.pone.0111913.

FarRelL, P., NelSON, K., 2013. Trophic level transfer of microplastics: Mytilus edulis (L.) to Carcinus maenas (L.). Environmental Pollution 177, 1-3. doi: 10.1016/j.envpol.2013.01.046.

FENDALL, L.S., SEWELL, M.A., 2009. Contributing to marine pollution by washing your face: Microplastics in facial cleansers. Marine Pollution Bulletin 58, 1225-1228. doi: 10.1016/j.marpolbul.2009.04.025.

Fisher, V., Elsner, N.O., Brenke, N., SchWABe, E., BRANDT, A., 2015. Plastic pollution of the KurilKamchatka Trench area (NW Pacific). Deep Sea Research // 111, 399-405. doi: 10.1016/j.dsr2.2014.08.012.

Fisner, M., TANiguchi, S., Majer, A.P., Bícego, M.C., TurRa, A., 2013a. Concentration and composition of polycyclic aromatic hydrocarbons (PAHs) in plastic pellets: Implications for small-scale diagnostic and environmental monitoring. Marine Pollution Bulletin 76, 349-354. doi: 10.1016/j.marpolbul.2013.09.045.

FISNeR, M., TANIGUCHI, S., MoreIRA, F., Bícego, M.C., TURRA, A., 2013b. Polycyclic aromatic hydrocarbons (PAHs) in plastic pellets: Variabillity in the concentration and composition at different sediment depths in a sandy beach. Marine Pollution Bulletin 70, 219-226. doi: 10.1016/j.marpolbul.2013.03.009.

Fotopoulou, K.N., KARAPANAGIOTI, H.K., 2012. Surface properties of beached plastic pellets. Marine Environmental Research 81, 70-77. doi: 10.1016/j.marenvres.2012.08.010. 
FrIAS, J., Sobral, P., FerReIRA, A.M., 2010. Organic pollutants in microplastics from two beaches of the Portuguese coast. Marine Pollution Bulletin 60, 1988-1992. doi: 10.1016/j.marpolbul.2010.07.030.

Fries, E., Dekiff, J.H., Willmeyer, J., Nuelle, M.-T., Ebert, M., Remy, D., 2013. Identification of polymer types and additives in marine microplastic particles using pyrolysis-GC/MS and scanning electron microscopy. Environmental Science: Processes \& Impacts 15, 1949-1956. doi: 10.1039/C3EM00214D.

GalganI, F., Hanke, G., Werner, S., De Vrees, L., 2013. Marine litter within the European Marine Strategy framework Directive. ICES Journal of Marine Science 70, 1055-1064. doi: 10.1093/icesjms/fst122.

GoLDSTEIN, M.C., GoodWIN, D.S., 2013. Gooseneck barnacles (Lepas spp.) ingest microplastic debris in the North Pacific Subtropical Gyre. PeerJ 10.7717/peerj.184.

Gouin, T., Roche, N., LoHmann, R., Hodges, G., 2011. A Thermodynamic Approach for Assessing the Environmental Exposure of Chemicals Absorbed to Microplastic. Environmental Science \& Technology 45, 1466-1472. doi: 10.1021/es1032025.

GrAHAM, E.R., THOMPSON, J.T., 2009. Deposit- and suspension-feeding sea cucumbers (Echinodermata) ingest plastic fragments. Journal of Experimental Marine Biology and Ecology 368, 22-29. doi: 10.1016/j.jembe.2008.09.007.

Gregory, M.R., 1977. Plastic pellets on New Zealand beaches. Marine Pollution Bulletin 8, 82-84. doi: 10.1016/0025-326X(77)90193-X.

Gregory, M.R., 1978. Accumulation and distribution of virgin plastic granules on New Zealand beaches. New Zealand Journal of Marine and Freshwater Research 12, 399-414. doi: 10.1080/00288330.1978.9515768.

GREGORY, M.R., 1983. Virgin plastic granules on some beaches of Eastern Canada and Bermuda. Marine Environmental Research 10, 73-92. doi: 10.1016/0141-1136(83)90011-9.

Gregory, M.R., ANDRADY, A.L., 2003. Plastics in the marine environment, in: Andrady, A.L. (Ed.), Plastics and the Environment. John Wiley \& Sons, Hoboken, New Jersey, pp. 379-402.

HARRISON, J.P., OJEDA, J.J., ROMERO-GONZÁLEZ, M.E., 2012. The applicability of reflectance micro-Fouriertransform infrared spectroscopy for the detection of synthetic microplastics in marine sediments. Science of the Total Environment 416, 455-463. doi: 10.1016/j.scitotenv.2011.11.078.

HARRISON, J.P., SCHRATZBERGER, M., SAPP, M., OsBORN, A.M., 2014. Rapid bacterial colonization of lowdensity polyethylene microplastics in coastal sediment microcosms. BMC Microbiology 14, 232. 
HeO, N.W., Hong, S.H., HAN, G.M., Hong, S., LeE, J., SONG, Y.K., JANG, M., SHIM, W.J., 2013. Distribution of small plastic debris in cross-section and high strandline on Heungnam Beach, South Korea. Ocean Science Journal 48, 225-233. doi: 10.1007/s12601-013-0019-9.

Heskett, M., Takada, H., Yamashita, R., Yuyama, M., Ito, M., Geok, Y.B., Ogata, Y., Kwan, C., Heckhausen, A., Taylor, H., Powell, T., Morishige, C., Young, D., Patterson, H., Robertson, B., Bailey, E., MERMOZ, J., 2011. Measurement of persistent organic pollutants (POPs) in plastic resin pellets from remote islands: Towards establishment of background concentrations for International Pellet Watch. Marine Pollution Bulletin 64, 445-448. doi: 10.1016/j.marpolbul.2011.11.004.

Hidalgo-Ruz, V., Gutow, L., Thompson, R.C., THIEL, M., 2012. Microplastics in the marine environment: a review of the methods used for identification and quantification. Environmental Science \& Technology 46, 3060-3075. doi: 10.1012/es2031505.

HIDAlgo-Ruz, V., THIEL, M., 2013. Distribution and abundance of small plastic debris on beaches in the SE Pacific (Chile): A study supported by a citizen science project. Marine Environmental Research 87-88, 12-18. doi: 10.1016/j.marenvres.2013.02.015.

Hiral, H., Takada, H., Ogata, Y., Yamashita, R., Mizukawa, K., Saha, M., Kwan, C., Moore, C., Gray, H., Laursen, D., Zettler, E.R., Farrington, J.W., Reddy, C.M., Peacock, E.E., Ward, M.W., 2011. Organic micropollutants in marine plastics debris from the open ocean and remote and urban beaches. Marine Pollution Bulletin 62, 1683-1692. doi: 10.1016/j.marpolbul.2011.06.004.

Holmes, L.A., TURner, A., ThOMPSON, R.C., 2012. Adsorption of trace metals to plastic resin pellets in the marine environment. Environmental Pollution 160, 42-48. doi: 10.1016/j.envpol.2011.08.052.

IMHOF, H.K., IVLEVA, N.P., SCHMID, J., NIESSNER, R., LAFORSCH, C., 2013. Contamination of beach sediments of a subalpine lake with microplastic particles. Current Biology 23, R867 - R868. doi: 10.1016/j.cub.2013.09.001.

IMHOF, H.K., SCHMID, J., NIESSNER, R., IVLEVA, N.P., LAFORSCH, C., 2012. A novel, highly efficient method for the separation and quantification of plastic particles in sediments of aquatic environments. Limnology and Oceanography: Methods 10, 524-537. doi: 10.4319/lom.2012.10.524.

ISMAIL, A., AdILAH, N.M.B., NURULHUdHA, M.J., 2009. Plastic pellets along Kuala Selangor-Sepang coastline. Malaysian Applied Biology 38, 85-88.

IVAR DO SUL, J.A., SPENGLER, Â., COSTA, M.F., 2009. Here, there and everywhere. Small plastic fragments and pellets on beaches of Fernando de Noronha (Equatorial Western Atlantic). Marine Pollution Bulletin 58, 1236-1238. doi: 10.1016/j.marpolbul.2009.05.004. 
Jambeck, J.R., Geyer, R., Wilcox, C., Siegler, T.R., Perryman, M., Andrady, A., Narayan, R., LaW, K.L., 2015. Plastic waste inputs from land into the ocean. Science 347, 768-771. doi: 10.1126/science.1260352.

JAYASIRI, H.B., PURUSHOTHAMAN, C.S., VenNILA, A., 2013. Quantitative analysis of plastic debris on recreational beaches in Mumbai, India. Marine Pollution Bulletin 77, 107-112. doi: 10.1016/j.marpolbul.2013.10.024.

Kaberi, H., Tsangaris, C., Zeri, C., Mousdisd, G., Papadopoulos, A., Streftaris, N., 2013. Microplastics along the shoreline of a Greek island (Kea isl., Aegean Sea): types and densities in relation to beach orientation, characteristics and proximity to sources, 4th International Conference on Environmental Management, Engineering, Planning and Economics (CEMEPE) and SECOTOX Conference, Mykonos Island, Greece, pp. 197-202.

$\mathrm{KACH}, \mathrm{D} . J .$, WARD, J.E., 2008. The role of marine aggregates in the ingestion of picoplankton-size particles by suspension-feeding molluscs. Marine Biology 153, 797-805. doi: 10.1007/s00227007-0852-4.

KarapanagiotI, H.K., Endo, S., OgatA, Y., TAKADA, H., 2011. Diffuse pollution by persistent organic pollutants as measured in plastic pellets sampled from various beaches in Greece. Marine Pollution Bulletin 62, 312-317. doi: 10.1016/j.marpolbul.2010.10.009.

KARAPANAGIOTI, H.K., KLONTZA, I., 2008. Testing phenanthrene distribution properties of virgin plastic pellets and plastic eroded pellets found on Lesvos island beaches (Greece). Marine Environmental Research 65, 283-290. doi: 10.1016/j.marenvres.2007.11.005.

KHORDAGUI, H.K., ABU- HILAL, A.H., 1994. Industrial plastic on the southern beaches of the Arabian Gulf and the western beaches of the Gulf of Oman. Environmental Pollution 84, 325-327. doi: 10.1016/0269-7491(94)90143-0.

KIM, I.-S., CHAE, D.-H., KIM, S.-K., CHOI, S., WOO, S.-B., 2015. Factors influencing the spatial variation of microplastics on high-tidal coastal beaches in Korea. Archives of Environmental Contamination and Toxicology. Advanced online publication. doi: 10.1007/s00244-015-01556.

KLostermanN, F., 2012. Occurrence and distribution of mesoplastics in sediments at the Mediterranean Sea coast. Thesis for the degree of Bachelor, University of Osnabrueck, pp. 51.

Koelmans, A.A., BEsseling, E., Wegner, A., Foekema, E.M., 2013. Plastic as a carrier of POPs to aquatic organisms: A model analysis. Environmental Science \& Technology 47, 7812-7820. doi: 10.1021/es401169n.

Koelmans, A.A., BEsSELING, A., FoekeMA, E.M., 2014. Leaching of plastic additives to marine organisms. Environmental Pollution 187, 49-54. doi: http://dx.doi.org/10.1016/j.envpol.2013.12.013. 
Kuriyama, Y., Konishi, K., Kanehiro, H., Otake, C., Kaminuma, T., Mato, Y., Takada, H., Kojima, A., 2002. Plastic pellets in the marine environment of Tokyo Bay and Sagami Bay. Nippon Suisan Gakkaishi 68, 167-171.

laglbauer, B.J.L., Franco-Santos, R.M., Andreu-Cazenave, M., Brunelli, L., Papadatou, M., Palatinus, A., GREGO, M., DePREZ, T., 2014. Macrodebris and microplastics from beaches in Slovenia. Marine Pollution Bulletin 89, 356-366. doi: 10.1016/j.marpolbul.2014.09.036.

Law, K.L., Moret-Ferguson, S., Maximenko, N.A., Proskurowski, G., Peacock, E.E., Hafner, J., Reddy, C.M., 2010. Plastic Accumulation in the North Atlantic Subtropical Gyre. Science 329, 11851188. doi: 10.1126/science.1192321.

LeE, J., Hong, S., Song, Y.K., Hong, S.H., JANG, Y.J., JANG, M., HeO, N.W., HAN, G.M., LeE, M.J., KANG, D., SHIM, W.J., 2013. Relationships among the abundances of plastic debris in different size classes on beaches in South Korea. Marine Pollution Bulletin 77, 349-354. doi: 10.1016/j.marpolbul.2013.08.013.

LieBezeit, G., DubaISH, F., 2012. Microplastics in Beaches of the East Frisian Islands Spiekeroog and Kachelotplate. Bulletin of Environmental Contamination and Toxicology 89, 213-217. doi: 10.1007/s00128-012-0642-7.

LITHNER, D., LARSSON, A., DAVE, G., 2011. Environmental and health hazard ranking and assessment of plastic polymers based on chemical composition. Science of The Total Environment 409, 3309-3324. doi: 10.1016/j.scitotenv.2011.04.038.

LOBELLE, D., CUNLIFFE, M., 2011. Early microbial biofilm formation on marine plastic debris. Marine Pollution Bulletin 62, 197-200. doi: 10.1016/j.marpolbul.2010.10.013.

Long, M., Moriceau, B., Gallinari, M., Lambert, C., Huvet, A., Raffray, J., Soudant, P., 2015. Interaction between microplastics and phytoplankton aggregates: Impacts on their respective fates. Marine Chemistry. Advance online publication. doi: 10.1016/j.marchem.2015.04.003.

LUSHER, A.L., MCHUGH, M., THOMPSON, R.C. 2013. Occurrence of microplastics in the gastrointestinal tract of pelagic and demersal fish from the English Channel. Marine Pollution Bulletin 67, 9499. doi: 10.1016/j.marpolbul.2012.028.

MARTINS, J., SOBRAL, P., 2011. Plastic marine debris on the Portuguese coastline: A matter of size? Marine Pollution Bulletin 62, 1649-1653. doi: 10.1016/j.marpolbul.2011.09.028.

Mathalon, A., HILL, P., 2014. Microplastic fibers in the intertidal ecosystem surrounding Halifax Harbor, Nova Scotia. Marine Pollution Bulletin 81, 69-79. doi: 10.1016/j.marpolbul.2014.02.018.

MASÓ, M., GARCÉS, E., PAGÈS, F., CAMP, J., 2003. Drifting plastic debris as a potential vector for dispersing Harmful Algal Bloom (HAB) species. Scientia Marina 67, 107-111. doi: 10.3989/scimar.2003.67n1107. 
Mato, Y., Isobe, T., TAKAdA, H., KAnehiro, H., OHtake, C., Kaminuma, T., 2001. Plastic resin pellets as a transport medium for toxic chemicals in the marine environment. Environmental Science \& Technology 35, 318-324. doi: 10.1021/es0010498.

MCDeRMID, K.J., MCMULLEN, T.L., 2004. Quantitative analysis of small-plastic debris on beaches in the Hawaiian archipelago. Marine Pollution Bulletin 48, 790-794. doi: 10.1016/j.marpolbul.2003.10.017.

Mizukawa, K., Takada, H., Ito, M., Geok, Y.B., Hosoda, J., Yamashita, R., SAHA, M., SUzuki, S., Miguez, C., Frias, J., Antunes, J.C., Sobral, P., Santos, I.R., Micaelo, C., Ferreira, A.M., 2013. Monitoring of a wide range of organic micropollutants on the Portuguese coast using plastic resin pellets. Marine Pollution Bulletin 70, 296-302. doi: 10.1016/j.marpolbul.2013.02.008.

Moore, C.J., Moore, S.L., LeeCASTeR, M.K., WeisBerg, S.B., 2001. A Comparison of Plastic and Plankton in the North Pacific Central Gyre. Marine Pollution Bulletin 42, 1297-1300. doi: 10.1016/s0025-326x(01)00114-x.

MOORE, C.J., 2008. Synthetic polymers in the marine environment: A rapidly increasing, long-term threat. Environmental Research 108, 131-139. doi: 10.1016/j.envres.2008.07.025.

Morét-Ferguson, S., Law, K.L., Proskurowski, G., Murphy, E.K., Peacock, E.E., Reddy, C.M., 2010. The size, mass, and composition of plastic debris in the western North Atlantic Ocean. Marine Pollution Bulletin 60, 1873-1878. doi: 10.1016/j.marpolbul.2010.07.020.

MSFD GES TECHNICAL SUBGROUP ON MARINE LITTER, 2013. Monitoring Guidance for Marine Litter in European Seas, Draft Report. European Commission, Brussels.

MURRAY, F., COWIE, P.R., 2011. Plastic contamination in the decapod crustacean Nephrops norvegicus (Linnaeus, 1758). Marine Pollution Bulletin 62, 1207-1217. doi: 10.1016/j.marpolbul.2011.03.032.

NG, K.L., OBBARD, J.P., 2006. Prevalence of microplastics in Singapore's coastal marine environment. Marine Pollution Bulletin 52, 761-767. doi: 10.1016/j.marpolbul.2005.11.017. NOR, N.H.M., OBBARD, J.P., 2014. Microplastics in Singapore's coastal mangrove system. Marine Pollution Bulletin 79, 278-283. doi: 10.1016/j.marpolbul.2013.11.025.

NORÉN, F., 2007. Small plastic particles in coastal swedish waters. KIMO Sweden Report, pp. 11, Nuelle, M.-T., DeKIFF, J.H., ReMY, D., FRIES, E., 2014. A new analytical approach for monitoring microplastics in marine sediments. Environmental Pollution 184, 161-169. doi: 10.1016/j.envpol.2013.07.027. OSPAR (2010). JAMP Guidelines for Monitoring Contaminants in Biota. OSPAR Commission. pp 120. PlasticsEuROPE, 2013. Plastics - the Facts 2013. An analysis of European latest plastics production, demand and waste data. Plastics Europe: Association of Plastic Manufacturers, Brussels, pp. 40. 
RedDY, M.S., BASHA, S., AdIMURThy, S., RAMACHANDRAiah, G., 2006. Description of the small plastics fragments in marine sediments along the Alang-Sosiya ship-breaking yard, India. Estuarine Coastal and Shelf Science 68, 656-660. doi: 10.1016/j.ecss.2006.03.018.

Reisser, J., Shaw, J., Wilcox, C., Hardesty, B.D., Proietti, M., Thums, M., Pattiaratchi, C., 2013. Marine plastic pollution in waters around Australia: Characteristics, concentrations, and pathways. PLOS ONE 8, e80466. doi: 10.1371/journal.pone.0080466.

Reisser, J., Shaw, J., Hallegraeff, G., Proietti, M., Barnes, D.K.A., Thums, M., Wilcox, C., HaRdesty, B.D., PATtIARATCHI, C., 2014a. Millimeter-sized marine plastics: A new pelagic habitat for microorganisms and invertebrates. PLOS ONE 9, e100289. doi: 10.1371/journal.pone.0100289.

Reisser, J., Proietti, M., ShaW, J., Pattiaratchi, C., 2014b. Ingestion of plastics at sea: does debris size really matter? Frontiers in Marine Science 1, 70. doi: 10.3389/fmars.2014.00070.

RIOS, L.M., MOORE, C., JONES, P.R., 2007. Persistent organic pollutants carried by Synthetic polymers in the ocean environment. Marine Pollution Bulletin 54, 1230-1237. doi: 10.1016/j.marpolbul.2007.03.022. doi: 10.1016/j.trac.2014.10.011.

ROCHA-SANTOS, T., DUARTE, A.C., 2015. A critical overview of teh analytical approaches to the occurrence, the fate and the behavior of microplastics in the environment. Trends in Analytical Chemistry 65, 47-53.

ROCHMAN, C.M., HOH, E., KUROBE, T., TEH, S.J., 2013. Ingested plastic transfers hazardous chemicals to fish and induces hepatic stress. Scientific Reports 3, 3263. doi: 10.1038/srep03263.

RUMMEL, C. 2014. Occurrence and potential effects of plastic ingestion by pelagic and demersal fish from the North Sea and Baltic Sea Thesis for the degree of "Diplom Biologe", Johannes Gutenberg-Universität Mainz, pp. 89.

Ryan, P.G., Bouwman, H., Moloney, C.L., Yuyama, M., TAKAdA, H., 2012. Long-term decreases in persistent organic pollutants in South African coastal waters detected from beached polyethylene pellets. Marine Pollution Bulletin 64, 2756-2760. doi: 10.1016/j.marpolbul.2012.09.013.

SANCHEZ W, BENDER C, PORCHER J-M. 2014. Wild gudgeons (Gobio gobio) from French rivers are contaminated by microplastics: Preliminary study and first evidence. Environmental Research 128: 98-100. doi: 10.1016/j.envres.2013.11.004.

Setälä, O., Fleming-Lehtinen, V., Lehtiniemi, M., 2014. Ingestion and transfer of microplastics in the planktonic food web. Environmental Pollution 185, 77-83. doi: 10.1016/j.envpol.3012.10.013. SHIBER, J.G., 1979. Plastic pellets on the coast of Lebanon. Marine Pollution Bulletin 10, 28-30. doi: 10.1016/0025-326X(79)90321-7. 
SHIBER, J.G., 1982. Plastic pellets on Spain's 'Costa del Sol' beaches. Marine Pollution Bulletin 13, 409412. doi: $10.1016 / 0025-326 \times(82) 90014-5$.

SHIBER, J.G., 1987. Plastic pellets and tar on Spain's Mediterranean beaches. Marine Pollution Bulletin 18, 84-86. doi: 10.1016/0025-326X(87)90573-X.

SONG, Y.K., HoNG, S.H., JANG, M., KANG, J.-H., KWON, O.Y., HAN, G.M., SHIM, W.J., 2014. Large Accumulation of Micro-sized Synthetic Polymer Particles in the Sea Surface Microlayer. Environmental Science \& Technology 48, 9014-9021. doi: 10.1021/es501757s.

SONG, Y.K., Hong, S.H., JANG, M., HAN, G.M., RANI, M., LEE, J., SHIM, W.J., 2015. A comparison of microscopic and spectroscopic identification methods for analysis of microplastics in environmental samples. Marine Pollution Bulletin 93, 220-209.

STALEY JT, KONOPKA A., 1985. Measurement of in-situ activities of nonphotosynthetic microorganisms in aquatic and terrestrial habitats. Annual Review of Microbiology 39, 321-346. doi: 10.1146/annurev.mi.39.100185.001541.

Strand, J., LASSEN, P., Shashoua, Y., Andersen, J.H., 2013. Microplastic particles in sediments from Danish waters, Poster at the ICES Annual Conference Reykjavik, Iceland.

Thain, J.E., VethaAK, A.D. AND HyLland, K., 2008. Contaminants in marine ecosystems: developing an integrated indicator framework using biological-effect techniques. ICES Journal of Marine Science 65, 1508-1514. doi: 10.1093/icesjms/fsn120.

Thompson, R.C., Olsen, Y., Mitchell, R.P., DaVIS, A., Rowland, S.J., JOHn, A.W.G., McGonigle, D., Russell, A.E., 2004. Lost at sea: Where is all the plastic? Science 304, 838-838. doi: 10.1126/science.1094559.

THORNTON, L., JACKSON, N.L., 1998. Spatial and temporal variations in debris accumulation and composition on an estuarine shoreline, Cliffwood Beach, New Jersey, USA. Marine Pollution Bulletin 36, 705-711. doi: 10.1016/s0025-326x(98)00041-1.

TURNER, A., HOLMES, L., 2011. Occurrence, distribution and characteristics of beached plastic production pellets on the island of Malta (central Mediterranean). Marine Pollution Bulletin 62, 377-381. doi: 10.1016/j.marpolbul.2010.09.027.

TurRa, A., Manzano, A.B., Dias, R.J.S., Mahiques, M.M., Barbosa, L., Balthazar-Silva, D., Moreira, F.T., 2014. Three-dimensional distribution of plastic pellets in sandy beaches: shifting paradigms. Scientific Reports 4, 4435. doi: 10.1038/srep04435.

Van, A., Rochman, C.M., Flores, E.M., Hill, K.L., Vargas, E., Vargas, S.A., Hoh, E., 2012. Persistent organic pollutants in plastic marine debris found on beaches in San Diego, California. Chemosphere 86, 258-263. doi: 10.1016/j.chemosphere.2011.09.039. 
Van Cauwenberghe, L., Claessens, M., Vandegehuchte, M.B., Mees, J., Janssen, C.R., 2013a. Assessment of marine debris on the Belgian Continental Shelf. Marine Pollution Bulletin 73, 161-169. doi: 10.1016/j.marpolbul.2013.05.026.

Van Caumenberghe, L., Vanreusel, A., Mees, J., Janssen, C.R., 2013b. Microplastic pollution in deep-sea sediments. Environmental Pollution 182, 495-499. doi: 10.1016/j.envpol.2013.08.013.

VAn CAUWenberghe, L., JANSSEN, C.R., 2014. Microplastics in bivalves cultured for human consumption. Environmental Pollution 193, 65-70. doi: 10.1016/j.envpol.2014.06.010.

Van Caumenberghe, L., Claessens, M., Vandegehuchte, M., Janssen, C. R., 2015. Microplastics are taken up by mussels (Mytilus edulis) and lugworms (Arenicola marina) living in natural habitats Environmental Pollution 199, 10-17. doi: 10.1016/j.envpol.2015.01.008.

Van Hoey, G., Borja, A., Birchenough, S., Buhl-Mortensen, L., Degraer, S., Fleischer, D., Kerckhof, F., MAGNI, P., MuXIKA, I., ReISS, H., SCHROder, A., ZetTLER, M.L., 2010. The use of benthic indicators in Europe: from the water framework directive to the marine strategy framework directive. Marine Pollution Bulletin 60, 2187-2196. doi: 10.1016/j.marpolbul.2010.09.015.

Vianello, A., Boldrin, A., Guerriero, P., Moschino, V., Rella, R., Sturaro, A., Da Ros, L., 2013. Microplastic particles in sediments of Lagoon of Venice, Italy: First observations on occurrence, spatial patterns and identification. Estuarine, Coastal and Shelf Science 130, 5461. doi: 10.1016/j.ecss.2013.03.022.

Von Moos, N., BURKHARDT-Holm, P., KoehleR, A., 2012. Uptake and effects of microplastics on cells and tissues of the blue mussel Mytilus edulis L. after experimental exposure. Environmental Science \& Technology 46, 11327-11335. doi: 10.1021/es302332w.

WARD, J.E., KACH, D.J., 2009. Marine aggregates facilitate ingestion of nanoparticles by suspensionfeeding bivalves. Marine Environmental Research 68, 137e142. doi: 10.1016/j.marenvres.2009.05.002.

Watts, A.J.R., LeWIS, C., GOOdHeAd, R.M., BeCKetT, S.J., Moger, J., TYLeR, C.R., GalloWAY, T.S., 2014. Uptake and Retention of Microplastics by the Shore Crab Carcinus maenas. Environmental Science \& Technology 48, 8823-8830. doi: 10.1021/es501090e.

Wegner, A., Besseling, E., Foekema, E.M., Kamermans, P., Koelmans, A.A., 2012. Effects of nanopolystyrene on the feeding behaviour of the Blue Mussel (Mytilus edulis L.). Environmental Toxicology and Chemistry 31, 2490-2497. doi: 10.1002/etc.1984.

Woodall, L.C., GWinnett, C., PACKer, M., Thompson, R.C., Robinson, L.F., PATERSON, G.L.J., 2015. Using a forensic science approach to minimize environmental contamination and to identify microfibres in marine sediments. Marine Pollution Bulletin. Advance online publication. doi: 10.1016/j.marpolbul.2015.04.044. 
1023

1024

1025

1026

1027

1028

1029

1030

1031

1032

1033

1034

1035

1036

1037

WRIGHT, S. L.; THOMPSON, R. C.; GallowAY, T. S., 2013a.The physical impacts of microplastics on marine organisms: A review. Environmental Pollution, 178, 483-492.

WRIGHT, S.L., ROWE, D., THOMPSON, R.C., GallowAY, T.S., 2013b. Microplastic ingestion decreases energy reserves in marine worms. Current Biology 23, R1031-R1033. doi: 10.1016/j.cub.2013.10.068.

Zettler, E.R., Mincer, T.J., Amaral-Zettler, L.A., 2013. Life in the "Plastisphere": Microbial Communities on Plastic Marine Debris. Environmental Science \& Technology 47, 7137-7146. doi: $10.1021 /$ es401288x.

ZHAO, S., ZHU, L., WANG, T., LI, D., 2014. Suspended microplastics in the surface water of the Yangtze Estuary System, China: First observations on occurrence, distribution. Marine Pollution Bulletin 86, 562-568. doi: 10.1016/j.marpolbul.2014.06.032.

ZITKO, V., HANLON, M., 1991. Another source of pollution by plastics: Skin cleaners with plastic scrubbers. Marine Pollution Bulletin 22, 41-42. doi: 10.1016/0025-326X(91)90444-W.

ZURCHER, N.A., 2009. Small plastic debris on beaches in Hong Kong: an initial investigation. Thesis for the degree of Master of Science in Environmental Management, Hong Kong University, p. 75. 